\title{
"Gorilas" no imaginário colonial: fantasias sexuais em torno do liame entre o humano e o bestial
}

Gorillas in the colonial imaginary: sexual fantasies in-between the human and the bestial

\section{Sílvio Marcus de Souza Correa}

\section{(2) OpenEdition}

Edição electrónica

URL: https://journals.openedition.org/aa/8315

DOI: 10.4000/aa.8315

ISSN: 2357-738X

\section{Editora}

Programa de Pós-Graduação em Antropologia Social (UnB)

Edição impressa

Paginação: 36-65

ISSN: 0102-4302

\section{Refêrencia eletrónica}

Sílvio Marcus de Souza Correa, «"Gorilas" no imaginário colonial: fantasias sexuais em torno do liame entre o humano e o bestial», Anuário Antropológico [Online], v.46 n.2 | 2021, posto online no dia 30 maio 2021, consultado o 01 junho 2021. URL: http://journals.openedition.org/aa/8315 ; DOI: https://doi.org/ 10.4000/aa.8315

\section{(c) (i) (9)}

Anuário Antropológico is licensed under a Creative Commons Atribuição-Uso Não-Comercial-Proibição de realização de Obras Derivadas 4.0 International. 


\section{anuário antropológico \\ v. $46 \cdot \mathrm{n}^{\circ} 2 \cdot \mathrm{majo-agosto} \cdot 2 \odot 21.2$}

\section{“Gorilas” no imaginário colonial: Fantasias sexuais em torno do liame entre o humano e o bestial}

Gorillas in the colonial imaginary: sexual fantasies in-between the human and the bestial

DOI: https://doi.org/10.4000/aa.8315

\section{Sílvio Marcus de Souza Correa}

Universidade Federal de Santa Catarina, Centro de Filosofia e Ciências Humanas, Depar-

tamento de História, Florianópolis, SC, Brasil

Professor associado do Departamento de História da Universidade Federal de Santa Catarina (UFSC) e membro do corpo docente permanente dos Programas de Pós-Graduação em História Global e Interdisciplinar em Ciências Humanas da UFSC. Suas pesquisas mais recentes tratam de ciência, impérios e colonialismo.

A descoberta científica do gorila ensejou nova polêmica em torno da classificação dos primatas. Como classificá-lo entre os hominídeos? A curiosidade científica e popular deu azo a fantasias em torno do maior primata. Qual seria o seu comportamento sexual? No imaginário colonial, o gorila esteve por muito tempo entre o humano e o bestial. Para alguns, o gorila era o elo perdido da evolução humana, para outros uma raça degenerada. Essa ambiguidade marca a produção de sentidos, notadamente aquela de viés racista. Discute-se também sobre eventuais permanências e desdobramentos dessas fantasias em meados do século XX.

Gorila. Imaginário colonial. Racismo. Representações artísticas. Fantasias sexuais.
The scientific discovery of the gorilla brought new altercations regarding the classification of primates. How to allot the gorilla among the hominids? Popular and scientific curiosity incited fantasies with the largest primate. What would be its sexual behavior? In the colonial imaginary, the gorilla has long been between the human and the bestial. Some claimed the gorilla was the missing link of human evolution; others thought it was a degenerate race. Such ambiguity characterizes the production of meanings about the gorilla, notably that with racist tones. The paper also addresses the possible permanence and unfolding of such fantasies in the mid-twentieth century.

Gorilla. Colonial imaginary. Racism. Artistic representations. Sexual fantasies. 


\section{Considerações preliminares}

O presente artigo procura deslindar algumas fantasias em torno do gorila à época dos impérios coloniais. Desde meados do século XIX, o maior primata do reino animal se tornou um monstro de uma África fantasmagórica. A polissemia do gorila advém, em grande parte, do racismo. Por conseguinte, a copiosa iconografia do gorila entre 1850 e 1930 mais informa sobre o imaginário ocidental do que sobre o próprio animal.

Deparei-me com uma primeira documentação sobre os gorilas quando estudava a "caça grossa” (Big Game) na África colonial (Correa, 2011). Durante a pesquisa sobre a representação da África e dos africanos, chamou-me a atenção a profusão de imagens do gorila como raptor de mulheres. Nos últimos anos, tenho coligido imagens de gorilas em arquivos e bibliotecas da Europa e também da África. Durante um período de residência como pesquisador no Instituto de Estudos Avançados de Paris tive a oportunidade de fazer uma recolha mais sistemática de fontes, sobretudo nos arquivos de museus de história natural de Berlim, Paris e Lisboa.

Naquela altura, consultei uma copiosa documentação sobre os gorilas. Relatos de viajantes, primeiros artigos científicos sobre o gorila, regulamentos sobre a caça na África, obras de arte, matérias de jornais e de revistas de cinema foram algumas das fontes do heteróclito corpus documental constituído nos últimos anos. Do corpus iconográfico, destacam-se várias imagens de uma escultura de Emmanuel Frémiet (1824-1910) e as caricaturas na imprensa ilustrada alemã entre

1914 e 1924 inspiradas nessa famosa obra do escultor francês. Como seria impossível reproduzir todas essas imagens e muitas delas demandariam autorização para eventual publicação, além de custos adicionais, optei por indicar as referências em nota de rodapé ao longo do texto para aquelas que se encontram em coleções digitais.

No que concerne à metodologia, cabe ressaltar que as imagens de gorilas em diferentes suportes materiais constituem um corpus iconográfico diverso e sobre o qual a abordagem transversal foi a alternativa encontrada para contornar as especialidades técnicas. Em geral, as imagens de gorilas são tratadas separadamente por especialistas da literatura, das artes plásticas, das artes gráficas, da fotografia e do cinema. Como o meu propósito era justamente analisar o que faz das unidades de minha amostra um conjunto válido para tratar das fantasias sexuais em torno do gorila raptor de mulheres, a análise das imagens reteve as variantes ficcionais de uma constância na representação do gorila como animal lascivo.

Meus primeiros artigos sobre as fantasias em torno dos gorilas foram publicados em 2015. Desde então, a recolha de imagens em diferentes suportes materiais ocorreu de forma mais aleatória e esporádica, pois as minhas pesquisas realizadas com financiamento de agências nacionais não tinham os grandes símios por tema principal. No entanto, os gorilas continuavam a emergir das fontes e o acaso fez com que eles voltassem a ser tema principal do presente artigo.

Ao passo que coligia as imagens de gorilas em gravuras, caricaturas, obras de arte, fotografias e filmes, percebia o quanto muitas delas estavam relacionadas 
ao binômio colonialismo e racismo. Identifiquei, num conjunto de imagens de gorilas, uma confluência fantasiosa dos racismos científico e popular. Do monstro raptor de mulheres ao gorila "elo perdido" da cadeia evolutiva, do sátiro lendário aos "gorilas" das tropas coloniais, essas imagens contêm elementos ecléticos de teorias raciais, de políticas coloniais e de uma moral burguesa.

Os trabalhos de Ann Laura Stoler (1989, 1995, 2002), Anne McClintock (1995) e Robert Young (1995) sobre sexualidade, raça e colonialismo foram fundamentais para pensar possíveis combinações entre racismo e poder colonial. Outros aportes sobre racismo e sexualidade (Epprecht, 2010; Thomas, 2007; Lyons, 2004) e sobre o conteúdo ficcional em torno dos gorilas (Jones, 2006; Giles-Vernick; Rupp, 2006) permitiram afinar a compreensão do problema. Cabe ressaltar que algumas percepções africanas da fronteira entre o humano e o gorila não têm o racismo por demarcador (Oishi, 2013; Mouguiama-Dauoda, 2007; Giles-Vernick; Rupp, 2006).

Algumas pistas subjacentes no corpus documental indicavam um outro caminho a seguir, uma senda tortuosa para quem não tem formação na área da psicanálise. Como leitor amador de Freud, procurei evitar qualquer reducionismo ao submeter o material coligido à teoria freudiana, notadamente no que concerne ao complexo de Édipo. Porém, minha leitura leiga não tem a menor pretensão de propor uma nova interpretação sobre as fantasias em torno do gorila raptor de mulheres. Busquei compreender por que essas imagens desagradaram ou chocaram, inclusive aquelas produzidas para alarmar a população com o propalado "perigo negro". Essas imagens de gorila raptor de mulheres remetem à tríade ansiedade/ perigo/desamparo da teoria freudiana e que, por sua vez, pode ajudar a entender o racismo enquanto parte de um sistema defensivo de um comportamento neurótico, como apresentarei mais adiante pela chave de leitura do complexo de Édipo.

Bronislaw Malinowski (1927) foi um dos primeiros antropólogos a criticar a validade do complexo de Édipo. Outros antropólogos e historiadores foram reticentes à teoria freudiana. $\mathrm{O}$ psiquiatra e escritor Frantz Fanon duvidou também da universalidade do complexo de Édipo, uma vez que Freud não pensara no "homem negro" (Fanon, 1952, p. 125-126). Ao mesmo tempo, Fanon (1952, p. 9) apostava na interpretação psicanalítica do "problema negro", embora o seu conhecimento da obra de Freud fosse por demais lacunar. ${ }^{1}$

As observações clínicas e etnográficas recolhidas entre 1962 e 1966 por Edmond e Marie-Cécile Ortigues (1989) permitiram formular a teoria do Édipo africano. Casos clínicos no Senegal deram sustentação à tese de que a imagem do pai tende a se confundir com a imagem da autoridade coletiva ou do ancestral (Ortigues, 1989, p. 73). O Édipo africano veio integrar um repertório que validava o caráter universal da descoberta freudiana. Segundo Peter Gay (1989, p. 87), “um dos aspectos mais proeminentes e ainda assim menos considerados do complexo de Édipo é a sua interação com a cultura", o que denota uma dimensão histórica indelével.

Ao levar em conta a modulação do complexo de Édipo e o modo variado de repressão instintual em cada cultura, pude relacionar algumas fantasias com um tipo de ansiedade neurótica a partir de um arsenal teórico que Freud desenvol-
Segundo David Macey (2012, p. 203), Fanon tinha uma prática limitada da psicanálise e o seu conhecimento da disciplina era mais literário e um tanto eclético. 
veu ao longo de décadas. Das representações do gorila no imaginário colonial, algumas delas denotam uma ansiedade compartilhada por homens e mulheres que, provavelmente, tinham em comum a mesma cultura e moral repressivas. Nesse sentido, procurei nas fantasias em torno do gorila elementos comuns de um processo civilizatório que, desde os meados do século XIX, foi marcado por uma "moral sexual cultural" que explica a "nervosidade moderna" (Freud, 1908) e, em certa medida, o racismo.

Se Freud tratou da estranheza, da hostilidade, da agressividade e da intolerância diante da diferença, ele não abordou o racismo. Porém, o racismo poderia derivar do que ele chamou de "narcisismo das pequenas diferenças" (Freud, 1918, p. 219). A interpretação fanoniana do racismo recupera elementos da teoria freudiana e, ao mesmo tempo, faz um paralelo entre antissemitismo e racismo a partir da filosofia de Jean-Paul Sartre, notadamente o ensaio sobre a "questão judaica", publicado em 1946. Curiosamente, a figura do gorila serviu para representar judeus e negros, como abordarei na sexta sessão do presente artigo.

No livro Pele negra, máscaras brancas, o seu autor tratou o racismo como uma patologia social (Fanon, 1952, p. 73). Trata-se de uma análise inovadora sobre erotismo, racismo e colonialismo (Thomas, 2007, p. 76). Frantz Fanon inaugura uma psicologia crítica, uma politização da psicologia (Hook, 2004, p. 115). Ao abordar certas fantasias sexuais de homens e mulheres em correlação com psicopatologias decorrentes do contexto colonial, ele notou que o racismo traduzia um sintoma defensivo, possivelmente relacionado com a ansiedade do homem branco e a sua obsessão em representar o homem negro como um adversário sexual. Porém, Fanon não enveredou por esse caminho que poderia levar a uma correlação entre essa obsessão e o complexo de Édipo. Dito de outra maneira, a suposta obsessão em representar o homem negro como um rival sexual poderia ter interface com o recalque da pulsão instintual da fase edipiana, ou seja, da rivalidade perturbadora para a criança diante do adversário original.

$\mathrm{Na}$ teoria freudiana, o sentimento de desamparo (Hilflosigkeit) da criança deriva daquele de perda do objeto amoroso (a mãe) para o "pai-rival”. Dessa situação traumática decorre uma ansiedade (Angst). A ansiedade tem sempre relação com uma expectativa. $\mathrm{Na}$ ansiedade realística, o perigo é conhecido, enquanto que na ansiedade neurótica ele é desconhecido. Em alguns casos, elas podem se mesclar (Freud, 1926, p. 303). Ainda segundo Freud, diante de um perigo real, uma ansiedade desproporcionalmente maior pode acusar a presença de um elemento neurótico. Assim, a obsessão de representar o homem negro como um adversário sexual pode indicar uma ansiedade neurótica.

A tríade ansiedade/perigo/desamparo (Angst/Gefahr/Hilflosigkeit) parece fundamental para compreender a possível relação entre ansiedade e racismo. A ansiedade resulta de uma percepção individual de um perigo (real ou imaginário) e diante do qual o indivíduo procura se proteger. Nesse sentido, o racismo seria um sintoma defensivo (Fanon, 1952, p. 139). A hipersexualização do homem negro não deixa de ser um dos desdobramentos dessa obsessão apontada por Fanon e que tem também paralelo com as fantasias sexuais em torno do gorila².
2 Há uma copiosa bibliografia sobre a hipersexualização do corpo negro e sua relação com o racismo, notadamente nos EUA e na África do Sul. A literatura norte-americana e a sul-africana têm privilegiado em suas análises o período da segunda metade do século XX, bem como as primeiras décadas do século XXI. Nos estudos pós-coloniais, a hipersexualização tem sido abordada ainda a partir da intersecção entre raça e gênero. 
Do corpus iconográfico sobre o gorila, selecionei imagens dele como raptor de mulheres, pois elas remetem a um nexo causal entre fantasia e ansiedade neurótica. As fantasias são produtos da imaginação humana e têm relação com a experiência vivida. Elas podem dar vazão a formas de satisfação imaginária dos desejos reprimidos. Para Freud (1908, p. 173-174), desejos insatisfeitos são as forças motrizes das fantasias, e toda imaginação é uma "realização" desses desejos, uma correção da realidade. As fantasias em torno do gorila têm sua história, elas decorrem da interação entre práticas, saberes e imaginários durante a época dos impérios coloniais. No caso do rapto de mulheres por gorila, procuro mostrar a seguir o quanto essa "lenda africana" foi transformada pelas artes plásticas, gráficas e visuais a partir de elementos do imaginário colonial e do racismo. Vale o adendo que Freud (1912) fez uma comparação entre as figuras do gorila e do pai da horda primitiva. Tomo essa comparação por fio de Ariadne para entrar nesse labirinto das fantasias em torno do gorila.

\section{Do "pai gorila"}

No famoso ensaio Totem e Tabu, há uma referência ao comportamento do gorila quando Sigmund Freud imagina o pai da horda primitiva. Na imaginação freudiana, a horda primitiva teria se livrado do macho-alfa e instaurado uma nova ordem, uma nova lei. $\mathrm{O}$ tabu do incesto teria sido um marco da passagem de um estado de natureza para um estado de cultura.

$\mathrm{O}$ autor de Totem e Tabu esperava que outras pesquisas pudessem validar o caráter universal do tabu do incesto. Antes da tese freudiana sobre o incesto, a interpretação sociológica de Émile Durkheim (1897) sobre as origens da exogamia já tinha abordado o incesto de forma distinta aos aportes anteriores de Mac Lennan (1865), Lubbock (1871) e Spencer (1873). Ela seria revisada meio século depois por Claude Lévi-Strauss (1949) em seu clássico As estruturas elementares do parentesco. No mesmo livro, o antropólogo francês fez uma crítica ao ensaio Totem e Tabu, de Sigmund Freud. A sua crítica é por demais conhecida para ser retomada aqui, assim como as críticas de outros antropólogos, como Alfred Kroeber e Bronislaw Malinowski. Para os fins deste trabalho, cabe ressaltar um ponto em comum entre Freud e Lévi-Strauss. Trata-se da interdição do incesto como lei universal.

Para Freud, o horror ao incesto (Inzestscheu) indicava algo obscuro que marcara indelevelmente a horda primitiva. Para Lévi-Strauss, a proibição do incesto fundamenta a ordem social e o seu sistema de trocas econômicas e sociais, inclusive em termos de mercado matrimonial. Resta sinalar que Freud e Lévi-Strauss não deixaram de considerar o "rapto ritual" já presente em várias etnografias para tratar da interdição do incesto e da exogamia por seu corolário.

Em várias partes do seu ensaio Totem e Tabu, Freud fez referência aos volumes de Totemism and Exogamy, de James George Frazer. Mas foram os trabalhos de Thomas Savage (1847) e de Charles Darwin (1871) que lhe deram subsídios para comparar a poligamia do gorila e a hipotética poligamia da horda primitiva (Freud, 1912, p. 410-411). O ensaio de Freud havia sido publicado pela primeira 
vez sob o título "Sobre algumas conformidades entre a vida mental dos Selvagens e dos Neuróticos" (Über einige Übereinstimmungen im Seelenleben der Wilden und der Neurotiker). Nota-se que a hipotética correlação entre a mentalidade do "selvagem" e do neurótico proposta por Freud tem paralelo com a "mentalidade primitiva" formulada por Lucien Lévy-Bruhl (1910). A aproximação da mentalidade do "selvagem" e do neurótico vai de par com aquela outra entre a suposta agressividade do gorila e a do homem primitivo. Segundo Freud (1930, p. 257), "o pai dos tempos pré-históricos era indubitavelmente terrível e uma quantidade extrema de agressividade lhe pode ser atribuída".

Ainda em Totem e Tabu, algumas ideias de Freud sobre a evolução humana encontram suporte na antropologia darwinista, sobretudo as pistas sobre simpatia e outros "instintos sociais" que permitiram o desenvolvimento do homem enquanto um ser moral. Em outro artigo, Freud (1921, p. 114) reconheceu a sua dívida com Darwin quando conjecturou que a forma primitiva da sociedade humana era uma horda governada despoticamente por um macho poderoso. Para ambos, o gorila serviu como arquétipo do homem primitivo. Porém, o que Freud (1912, p. 411) reteve sobre o gorila remonta às considerações de Darwin (1871, p. 346), que, por seu turno, valeu-se das informações de Savage (1847, p. 423) obtidas junto a caçadores anônimos da África equatorial. Nota-se que o conhecimento científico sobre o comportamento sexual e social do gorila não era baseado em observação direta sobre o animal em seu habitat até a década de 1920 (Akeley, 1923).

O que interessa para as análises a seguir é essa relação entre o comportamento sexual do gorila e do pai primitivo no ensaio de Freud (1912), pois ela enseja uma confusão entre o gorila e o homem primitivo. Ela tem ainda interface com a aproximação dos estudos de anatomia comparada entre o gorila e o homem africano nas teorias raciais desde os meados do século XIX.

As fantasias sexuais em torno do gorila permitem deslindar um tipo de retorno do recalcado. Em sentido metafórico, a figura do gorila raptor de mulheres representa a volta do pai tirano da horda primitiva. Para a teoria freudiana, o recalque é um processo psíquico através do qual alguns conteúdos da experiência, como lembranças e representações, são rejeitados pelo consciente. Esse "material" recalcado não é descartado totalmente, pois ele segue "arquivado" no inconsciente. Ao tratar do recalque, Freud já havia exposto a tendência desses conteúdos estocados no inconsciente reaparecerem como sintomas e atos falhos ou em sonhos e fantasias (Freud, 1915).

Devido à moral repressiva da sociedade burguesa do período do imperialismo colonial, a maioria dos indivíduos na Europa tinha dispositivos mentais para deixar-se afetar pelas ambiguidades em torno da figura do gorila. Alguns conteúdos recalcados, possivelmente relacionados com a figura paterna capaz de "raptar" o objeto de amor (a mãe) da criança e com a angústia da castração, podiam ser despertados diante das imagens do gorila raptor de mulheres. Nada impedia que angústias e pulsões reprimidas voltassem combinadas aos perigos e riscos de momentos históricos marcados pela chamada Partilha da África ${ }^{3}$.

Freud (1926, p. 231) distinguiu a ansiedade como uma reação direta e auto-
A Partilha da África (Scramble for Africa) corresponde ao período do final do século XIX ao início do século XX, quando algumas potências europeias "dividiram" entre si o continente africano. 
mática a um trauma e a ansiedade como um sinal de perigo. A ansiedade como um sinal é uma resposta do ego a uma ameaça que pode redundar numa situação traumática. A ansiedade teria ainda relação com a inibição do ego. A inibição seria efeito de uma restrição para evitar conflito entre as três instâncias dinâmicas do aparelho psíquico na teoria freudiana. Ao estudar a fobia a animais em dois casos clínicos, Freud (1926, p. 252) percebeu que a força motriz da repressão era o medo da castração. Dito de outra maneira, a ansiedade sentida em fobia a animais era o medo de castração do ego.

As relações entre libido, ansiedade, inibição e sintomas foram reformuladas por Freud ao longo de seus trabalhos. Pode-se obter neles alguns elementos para explorar a pista de que as fantasias sexuais em torno do gorila decorrem de uma convergência entre ideias e representações recalcadas e outras ideias e representações de "novos" perigos que provocam ansiedade. Por outro lado, as aproximações do gorila com o pai da horda primitiva e com o homem negro ensejam uma interpretação do racismo como resultado também de um mecanismo psíquico de defesa diante do possível retorno do recalcado.

As fantasias em torno do gorila como o raptor de mulheres podem ter correspondência com o que Freud chamou de "horror ao incesto" (Inzestscheu), que remete à pulsão reprimida em querer eliminar o adversário original (o pai). $\mathrm{O}$ tamanho e a força do adversário original intimidam a criança e frustram as suas expectativas de exclusividade em relação ao seu objeto de amor. Segundo Freud, o pai desempenha o papel do temível adversário dos interesses sexuais infantis. Pelo recalque, a criança "esquece" essa hostilidade e a sua pulsão parricida quando superado o complexo de Édipo (Freud, 1924). Entretanto, os desejos reprimidos continuam latentes no inconsciente.

O deslizamento da imagem do gorila raptor de mulheres para aquela do negro hipersexualizado pode ser um exemplo dessa combinação de representações reprimidas e de ansiedade neurótica. Para Frantz Fanon (1952, p. 139), o branco estava persuadido que o negro era um mero animal sexual. Por isso, a sua defesa era marcar a diferença, caracterizando o negro, que passa a ser o suporte de sua preocupação e de suas fantasias. O racismo seria um sintoma defensivo.

Segundo Hannah Arendt (1951, p. 185), neste período da Partilha da África, a raça substituiu a nação enquanto princípio de um corpo político. $O$ racismo foi um fundamento do colonialismo. Conforme as teorias raciais em voga à época dos impérios coloniais, as chamadas "raças inferiores" eram mais próximas da natureza do que da civilização. Em língua alemã, por exemplo, o termo Naturvölker para "povos primitivos" ou "povos selvagens" fez parte do jargão dos etnólogos até meados do século XX. A clivagem entre natureza e civilização era produto de uma visão do mundo assente em categorias binárias. Essa divisão entre natureza e civilização encontra-se também no ensaio freudiano sobre o mal-estar na civilização.

Na sociedade burguesa à época dos impérios coloniais, a coerção social e a repressão sexual ensejavam a compulsão ao trabalho como forma de sublimação. Mas os indivíduos conservavam uma aversão potencial à civilização que lhes enquadrava em suas regras e normas de conduta. O mal-estar da civilização (Freud, 
1930) advém dessa condição paradoxal, pois os indivíduos são protegidos e reprimidos pela civilização. A internalização das normas pelos indivíduos favorece uma ação coletiva de vigilância e censura em relação às eventuais transgressões das leis que fundamentam a ordem social.

A cultura do imperialismo e a sua moral burguesa repressiva não forjaram apenas o modelo de "homem civilizado", mas também o tipo de "selvagem". A este último foram imputados alguns apanágios que nada mais eram do que conteúdos recalcados no "homem civilizado". Essa invenção do "selvagem" como o outro do "homem civilizado" encontra uma similaridade com as fantasias em torno do gorila. Dito de outra maneira, o gorila podia representar no imaginário colonial o adversário original (o pai), como também o novo adversário (o outro, o negro, o selvagem...), já que certas características atribuídas às então chamadas "raças inferiores" eram vistas como impedimentos ou obstáculos à satisfação do autodenominado homem civilizado. A chance de o sentimento de desamparo causado por experiências traumáticas ou frustrações infantis ressurgir em contexto colonial e confundir-se com a ansiedade diante de uma nova situação poderia variar, pois na vida mental do indivíduo, o outro é com bastante regularidade tomado como um modelo, um objeto, um auxiliar e um adversário (Gay, 1989, p. 122).

Algumas fantasias do imaginário colonial apresentam indícios reveladores do complexo de Édipo ou dos recalques de homens e mulheres que compartilham a mesma moral burguesa. O próprio Fanon trouxe alguns exemplos da clínica em seu primeiro livro. As fantasias em torno da alteridade africana se encontram em trabalhos de cientistas e também de literatos, artistas plásticos e artistas gráficos entre 1870 e 1930. Um exemplo seria a transformação do homem negro em "criança grande" ou em "gorila”, duas representações que aparecem nas caricaturas de semanários satíricos da imprensa metropolitana. Conquanto as imagens de "criança grande" estavam relacionadas à emasculação do homem negro, as imagens de "gorila" sinalizavam a sua virilidade e mesmo a sua hipersexualização ${ }^{4}$. A hipersexualização do negro seria uma decorrência da animalização do corpo negro operada pelo racismo.

O racismo revela um sintoma que Fanon identificou na hipersexualização do homem negro, produto da fantasia mas também alvo da hostilidade do colonizador, já que o suposto corpo lúbrico representaria uma ameaça à ordem colonial. Uma chave de leitura que as pistas de Freud e Fanon indicam pode ser a seguinte: ao fazer do homem negro um rival sexual do homem branco, o imaginário colonial confundia o adversário primordial (pai) com o rival coevo (homem negro). Desse modo, o adversário original da criança edipiana podia ressurgir sob o fantasma do gorila ou do homem negro hipersexualizado.

O “pai gorila” não representa o elo perdido da evolução humana, apesar da importância do liame entre natureza e civilização para o pensamento freudiano. Cabe lembrar que a descoberta científica do gorila suscitou matérias sensacionalistas, nas quais o gorila foi apresentado como um fóssil vivo ou um monstro. Em sua arqueologia das ciências humanas, Michel Foucault empreendeu uma etnologia da cultura ocidental. Nela, lembrou que o fóssil permite reconstituir
4 Numa perspectiva antropológica sobre a hipersexualização dos africanos, Andrew e Herriet Lyons (2004) mostram como a sexualidade foi um dos objetos dos estudos da Antropologia na Grã-Bretanha e nos Estados Unidos. 
o percurso evolutivo e identificar algo com uma forma distante, enquanto que o monstro - como uma caricatura - demarca o desvio, a diferença aberrante (Foucault, 1966, p. 170). Por seu turno, Achille Mbembe (2013, p. 35) referiu-se a essas figuras do fóssil e do monstro para sugerir o Negro como síntese de ambas na fabulação ocidental do racismo moderno. Nota-se que o racismo mobilizou essas figuras de fóssil e de monstro para aproximar as representações do Gorila e do Negro. Do "negro gorila” para o "pai gorila”, o racismo pode indicar um atalho.

\section{Gorilas e o imaginário colonial}

Desde 1847, a descoberta científica do gorila suscitou uma gama de artigos científicos, sendo os principais decorrentes de estudos de anatomia comparada (Savage e Wyman, 1847; Savage, 1847; Saint-Hilaire, 1852; Owen, 1859). Algumas semelhanças entre o gorila e o ser humano deram azo a formulações racistas entre os defensores do poligenismo e mesmo entre os adeptos do transformis$\mathrm{mo}^{5}$. Também a imprensa internacional publicou matérias sobre o maioral dos primatas. Num hebdomadário nova-iorquino, o gorila aparece como "uma nova raça” de macaco capaz de proezas como assaltar aldeias e raptar jovens mulheres. A matéria informava ainda sobre a crença dos africanos de que os gorilas eram homens como eles (The Africans believe that gorillas are men like themselves) ${ }^{6}$. Meses depois, o gorila aparece como "uma caricatura gigantesca e grotesca do ser humano" (The Gorilla is a gigantic and grotesque caricature of the human being) ${ }^{7}$. Ainda em 1859, dois gorilas (macho e fêmea) foram representados como exemplos de "homem-macaco" numa matéria do mesmo semanário ilustrado. A matéria termina afirmando que o gorila era o animal mais próximo do ser humano e, ao mesmo tempo, superior em força e ferocidade aos mais terríveis animais da floresta (The more interesting as it is the race which approximates most closely to our own species, and yet which surpasses in strength and ferocity the most terrible denizens of the forest $)^{8}$.

Num semanário de Lisboa, uma pequena matéria ilustrada advertia os leitores sobre a opinião errônea, às vezes divulgada por "viajantes crédulos, pouco instruídos ou quiçá menos sinceros", que os grandes símios representavam uma raça degenerada de homens ${ }^{9}$.

Das florestas da África equatorial foram enviados os primeiros crânios e ossos de gorila para Boston, Paris e Londres. Em 1852, um primeiro corpo do animal chegou ao Museu Nacional de História Natural de Paris, onde o gênero gorila foi definido pelo naturalista Isidore Geofffroy Saint-Hilaire. Entre outros trabalhos seus, destaca-se um tratado de teratologia publicado entre 1832 e 1836. A classificação dos monstros seguiu o caminho aberto por seu pai, Etienne Geoffroy Saint-Hilaire, para quem a monstruosidade não era uma extravagância, uma aberração, uma negação da ordem natural, mas sim algo que os naturalistas podiam classificar e explicar cientificamente (Nouailles, 2017). A teratologia de Saint-Hilaire adotava algumas regras do sistema de Carl von Linneu. No seu Sistema Naturae, o naturalista sueco distinguiu as "raças" do Homo Sapiens e também tratou de monstros como os sátiros. Embora Isidore Geoffroy Saint-Hilaire tenha classificado o
5 O poligenismo foi uma teoria racial baseada na origem diversa das "raças humanas" e teve entre os seus defensores Georges Pouchet, autor do livro De la pluralité des races humaines (1858). Já o transformismo, foi uma teoria evolucionista que defendia a variação das espécies ao longo da história natural. Jean-Baptiste de Lamarck, autor de Philosophie zoologique (1809), foi um dos seus principais teóricos. As teses do transformismo minaram a base do chamado fixismo, que predominava no campo científico da primeira metade do século XIX (Faria, 2012; Goulven, 2001).

6 Harper's Weekly, New York, Harper \& Brothers, March 5, 1859 , p.148.

7 Harper's Weekly, New York, Harper \& Brothers, September 10, 1859, p.579.

8 Harper's Weekly, New York, Harper \& Brothers, November 12, 1859, p.723-724.

9 Archivo Pittoresco. Semanário Illustrado. Lisboa, 02.09.1858, p. 101 (Biblioteca Nacional de Portugal). 
gorila como um novo gênero, a taxonomia, a classificação e a nomenclatura ainda suscitavam algumas discordâncias entre os naturalistas. Ao passo que os relatos de viagem sobre o grande primata permitiam muita especulação em torno do propalado "homem-macaco", outras informações fabulosas circulavam sobre homens de cauda nos confins da África ${ }^{10}$. Segundo um jornal londrino, alguns modelos de cera desses monstros foram exibidos no museu do Doutor Kahn (Lindfors, 2011, p. 173) $)^{11}$.

Nesse período, os empresários do espetáculo, como Barnum e Farini, exploravam o exótico, o anormal e o monstruoso. Gigantes, anões, albinos, siameses, hermafroditas eram exibidos para um público metropolitano, bem como os chamados hotentotes, bosquímanos e pigmeus. Essas exibições do monstruoso e do exótico ocorriam em feiras, circos e também em outros novos espaços de entretenimento, como o jardim zoológico e as exposições coloniais ${ }^{12}$. A exibição se fazia ainda pelas imagens na imprensa periódica ilustrada, em cartazes e cartões postais. Essas formas de exibição da alteridade permitiam ao público espectador metropolitano elaborar representações sobre anormalidade e inferioridade racial, ao mesmo tempo em que o contraste favorecia a sua autorrepresentação.

Assim como as teorias raciais, o freak show e o ethno show concorreram para a ideia de superioridade racial do público espectador. A exibição da anormalidade e da atribuída inferioridade alheia oferecia aos europeus uma forma de assegurar a sua própria normalidade e pretensa superioridade. À época dos impérios coloniais, a euforia pelo progresso favorecia inventar um futuro, mas também um passado. Na propalada narrativa civilizacional podem as fantasias em torno da própria origem ser nada mais que lembranças encobridoras ${ }^{13}$. Cabe o adendo que Freud recorreu ao exemplo da tendenciosa história de povos antigos para abordar certas fantasias. Ao fantasiar as origens de sua própria história, escondem-se as fraquezas e/ou as dificuldades dos primeiros tempos (Freud, 1910, p. 110) ${ }^{14}$.

As fantasias operam como "fachadas psíquicas", como sagas pessoais, por meio das quais o sujeito vê o seu passado, a sua história. Na psicanálise, a fantasia pode ser um obstáculo, mas ela também é pista para interpretar certas experiências traumáticas. A descoberta científica do gorila fomentou muitas controversas sobre a evolução humana, sobre o passado dos hominídeos. As teorias raciais se modulam à essa sensacional descoberta. A superioridade racial propalada pelas teorias científicas à época dos impérios coloniais convive com outras fantasias como, por exemplo, o perigo da degeneração racial.

A descoberta científica do gorila instigava a imaginação sobre as origens do homem primitivo, ainda mais quando grupos chamados de pigmeus foram encontrados na mesma região onde habitavam os gorilas e outros grupos humanos supostamente antropófagos ${ }^{15}$. Pigmeus, canibais e gorilas representavam um universo fantástico, mas também um laboratório para a história natural dos meados do século XIX (Correa, 2008, p. 24). Juntamente com os espólios do gorila, o naturalista e missionário norte-americano Thomas Savage e o explorador francês e naturalizado norte-americano Paul Belloni du Chaillu, entre outros, recolheram informações sobre o comportamento do animal. Em seu livro Stories of the Gorilla
10 Mesmo na Bahia foram recolhidos relatos de escravos sobre os "homens de cauda" na África (Castelnau, 1851). O relato do francês Louis Couret (1854) também tratou dessas figuras monstruosas já referidas na literatura de viagens desde Marco Polo, mas também em obras de naturalistas como Carl von Linneu e Johann F. Blumenbach.

11 Formado em medicina na Alemanha, o doutor Joseph Kahn se instalou em Londres em 1851, onde abriu um museu de anatomia e patologia (Anatomical and Pathological Museum) na Oxford Street. Durante a segunda metade do século XIX, o museu do Dr. Kahn foi alvo de algumas polêmicas (Lindfors, 2011; Bates, 2006).

12 Sobre os "zoos humanos" ou o espetáculo do outro, ver, p. ex., Blanchard et al. (2002); Lindfors (1999).

13 Lembranças encobridoras (Deckerinnerungen) são certamente falsas, incompletas ou deslocadas no tempo e no espaço (Freud, 1917, p. 40). 14 Ao tratar da história de uma neurose infantil, Freud (1918, p. 140) recorreu à mesma comparação das fantasias sobre a infância com as sagas de grandes e orgulhosas nações que procuram cobrir a pequenez e a desventura de suas origens. Freud tratou ainda disso ao abordar as lembranças encobridoras (Deckerinnerungen).

15 Os grupos Baka e Fang da África equatorial foram considerados respectivamente como grupos de pigmeus e de antropófagos pelo caçador de gorilas Paul Belloni du Chaillu (1870; 1867; 1861). 
Country, Paul B. du Chaillu relatou que um homem se transformou em gorila. Essa crença lhe foi contada por um caçador nativo, o que vai ao encontro de outras narrativas de pessoas vizinhas à região onde habitam gorilas (Oishi, 2013; Mougiama-Dauoda, 2007; Giles-Vernick; Rupp, 2006). Entre as narrativas sobre as proezas do gorila, havia a crença no intercurso sexual com mulheres de aldeias circunvizinhas ao seu habitat. $\mathrm{O}$ rapto de mulheres por gorilas tornou-se uma das fantasias do imaginário social à época dos impérios coloniais, quando a ciência, com base nas teorias raciais, aproximou o gorila do homem negro.

Ao tratar do imaginário colonial, busca-se operar com imagens que tiveram sentidos para os grupos sociais envolvidos. Sabe-se que algumas imagens advêm de experiências passadas e que retornam sob outras formas, inclusive fantasiosas $^{16}$. Como produção social, essas imagens fantasiosas em torno do gorila dizem mais sobre os grupos que as produzem e seus receptores do que sobre o próprio animal. Cabe lembrar que cada indivíduo é parte componente de vários grupos e, por conseguinte, opera com valores, saberes e crenças desses grupos (Freud, 1921, p. 65-66). Cientistas, escritores, artistas plásticos e artistas gráficos operam com diferentes linguagens, todas compreensíveis para seus respectivos públicos. Essa condição básica da comunicação permitiu a difusão de informações sobre o gorila. Outrossim, as fantasias que "deformam" essas imagens do gorila podem derivar de mecanismos psíquicos de repressão instintual.

\section{0 gorila entre o homem e a besta}

Desde o primeiro artigo científico sobre o gorila (Savage, 1847) até a classificação da última subespécie (Matschie, 1914), o continente africano foi alvo de campanhas militares e de dominação colonial. Em termos cronológicos, as fantasias em torno do gorila coincidem, grosso modo, com as viagens de exploração pela África central. Elas coincidem também com o predomínio das teorias raciais, notadamente entre 1870 e 1930.

No livro Exploration and Adventures in Equatorial Africa, de Paul Belloni du Chaillu, pode-se perceber certa amálgama dessas teorias raciais difusas desde meados do século XIX. Suas hipóteses sobre as semelhanças entre chimpanzés, gorilas e humanos dão uma ideia dos seus conhecimentos de aspirante a naturalista. Encontram-se ainda no seu relato algumas informações recolhidas junto à população local sobre o gorila, como as narrativas de rapto de mulheres (Chaillu, 1861, p. 133). Essas stories, como as qualifica o caçador de gorilas, perderam alguns significados quando transpostas para um outro contexto cultural. Dito de outra maneira, os saberes locais sobre os gorilas foram tolhidos nos textos científicos e literários. As funções dos saberes locais para o controle social sobre mulheres e crianças entre os povos das florestas foram obliteradas por viajantes, missionários e naturalistas. Os dispositivos reguladores de ordem mítico-religiosa dos saberes locais em torno dos gorilas também foram ignorados pela ciência e pela literatura (Correa, 2015b, p. 129).

Segundo Paul B. du Chaillu, os nativos acreditavam que o gorila podia estar
16 Algumas imagens podem estar relacionadas com um recalque ou com aquilo que Freud (1917) chamou de lembranças encobridoras (Deckerinnerungen). 
habitado por um espírito de um antepassado humano. Os "possuídos" seriam mais sagazes do que os demais, já que o espírito humano incorporado agiria sobre a força bruta do seu hospedeiro. A inteligência estaria reunida ao vigor e à suposta lubricidade do animal. Em outro livro de aventuras, Stories of the Gorilla Country, o autor relatou o que ouviu de um caçador nativo sobre um homem que se transformou em gorila (Chaillu, 1867).

A ideia de gorilas "possuídos" por espíritos humanos pode ter sido interpretada diferentemente pelo missionário e naturalista Dr. Thomas Savage, que afirmou, em seu artigo na Boston Journal of Natural History (1847), que os nativos consideram os "orangos" como humanos degenerados. Provavelmente, os informantes do Dr. Savage não empregaram em língua pongwé um adjetivo correspondente ao termo em inglês degenerated. Pode ter sido um problema de tradução. Porém, ideias sobre a degeneração de espécies animais ou de raças humanas podiam ser encontradas em textos científicos e literários dos meados do século XIX (Percheron, 2019). Pode-se inferir que o próprio naturalista e missionário, imbuído da ideia de degeneração, interpretou a informação dos nativos enquadrando gorilas e chimpanzés ao esquema de "humanos degenerados" (Correa, 2015b, p. 124). A teoria da degeneração suscitou uma série de especulações sobre a possibilidade de haver uma raça degenerada "perdida" nas florestas africanas.

Novas descobertas causavam mais dúvidas sobre o "homem pré-histórico". Entre outras, destacou-se o estudo do naturalista dinamarquês Peter Wilhelm Lund sobre os vestígios humanos em sítios arqueológicos no Brasil. A descoberta científica de ossadas do "homem primitivo" na Província de Minas Gerais (Lund, 1844) e do gorila nas florestas da África equatorial (Savage, 1847) ocorreu sob o paradigma da paleontologia e da anatomia comparada, consolidado no primeiro quartel do século XIX, a partir dos métodos e do programa de pesquisa de Georges Cuvier. Mesmo que já houvesse sinais de uma crise epistemológica, os trabalhos de Cuvier mostraram a importância dos fósseis para a história natural (Faria, 2012, p. 207-208). No entanto, novas evidências de fósseis humanos levaram alguns naturalistas, como Charles Lyell e Thomas Huxley, a tratar a evolução humana a partir de um novo paradigma. Ao passo que Charles Darwin desenvolvia a sua teoria evolutiva da seleção natural e outros naturalistas britânicos aderiam à teoria darwinista, o eminente paleontólogo Richard Owen continuava a defender o paradigma de Cuvier. Defendeu também o aventureiro e aspirante a naturalista Paul B. du Chaillu acusado por seus detratores de exagerar, de plagiar, de inventar e buscar o sensacional em seus relatos (Merlet, 2007, p. 38). Além de relatos de viagem e livros de aventuras, Paul B. du Chaillu publicou alguns artigos científicos tratando, entre outros temas, de anatomia comparada entre primatas e sobre as populações do estuário do Gabão ${ }^{17}$. Apesar das críticas no meio acadêmico, o caçador de gorilas ganhou notoriedade com suas conferências e suas stories sobre os gorilas, o que contribuía para a confusão em alguns leitores cismados com a possibilidade de o gorila ser um "homem-macaco", um "fóssil vivo" ou um elo-perdido da evolução humana.
17 Entre 1860 e 1870, Paul B. du Chaillu publicou uma dezena de artigos em periódicos científicos como Proceedings of Natural History Society of Boston, Bulletin de la Société de Géographie de Paris e American Geographical and Statistical Society Journal. 


\section{Um rapto hediondo}

Com a descoberta científica do maior primata, o lendário rapto de mulheres por sátiros ganhou uma nova personagem no imaginário europeu. Dessa vez, tornou-se a lenda mais credível pelo tamanho e pela força do gorila macho adulto. A especulação sobre o possível intercurso sexual entre humanos e macacos já aparece na literatura de viagem antes mesmo da descoberta científica do gorila. Durante a sua estadia em Madagascar, em outubro de 1648, Jean Struys referiu-se a grandes macacos bípedes que podiam cometer um estupro coletivo ao encontrar uma mulher (Struys, 1861, p. 16). Em sua Descrição da África (1686), o holandês Olfert Dapper (1989, p. 297) compilou muitas informações, inclusive sobre "Sátiros" no reino de Angola e sobre os quais "os negros dizem coisas prodigiosas", como o fato desse animal tomar à força mulheres e jovens e mesmo ousar investir contra homens armados. Para Dapper, esse animal [o gorila] seria o Sátiro já célebre entre Plínio e os poetas antigos que o conheciam por ouvir dizer ou por relatos incer$\operatorname{tos}^{18}$. Nos séculos seguintes, surgem novas referências ao intercurso sexual entre mulheres e grandes macacos em obras literárias de Voltaire e Alfred de Musset. Porém, tanto em Candide quanto em Gamiani ou deux nuits d'excès, não se trata de estupro $^{19}$. A imagem de rapto de mulheres por grandes símios aparece também em gravuras do final do século XVIII.

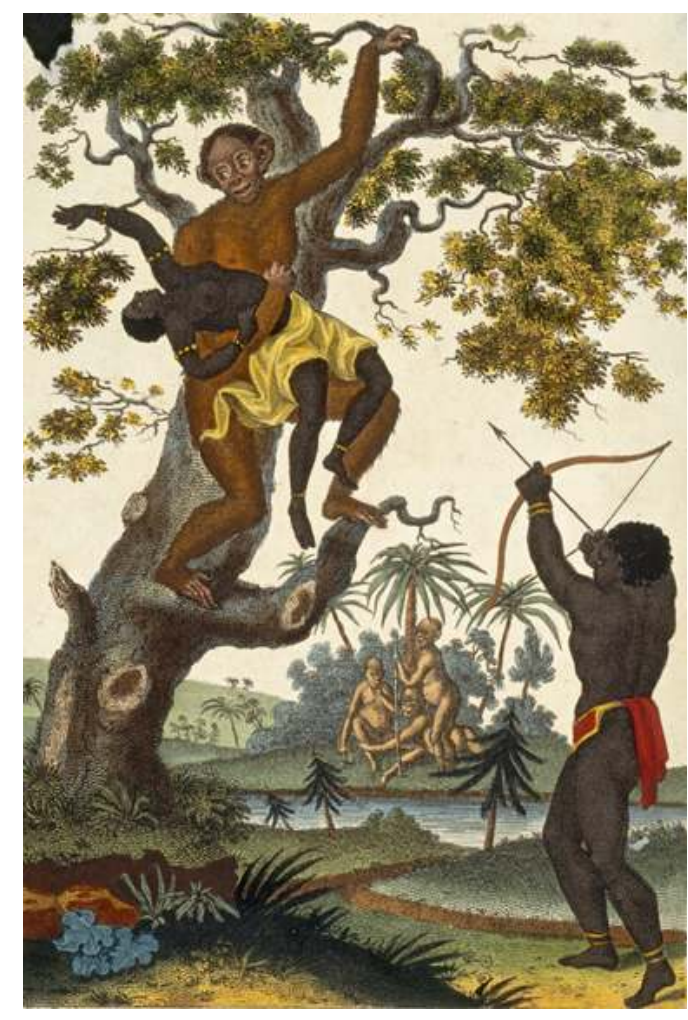

O rapto de mulheres por gorilas veio integrar um imaginário do qual também fazia parte o rapto de Helena, das Sabinas e mesmo da deusa Perséfone. A imaginação em torno desses raptos da mitologia greco-romana já era tributária de uma tradição pictórica desde o Renascimento. Pintores como Guido Reni, Nicolas Poussin,
18 Dapper se refere, entre outros, ao Périplo de Hanão, um cartaginês que teria viajado pelo Oceano Atlântico até a costa da África central e ao relato de Andrew Battel, aventureiro inglês que foi prisioneiro dos portugueses em Angola e cuja experiência africana foi publicada por Samuel Purchas em 1614.

19 Da literatura contemporânea, vale lembrar o best-seller The Woman and the Ape, do dinamarquês Peter Høeg (1996).

Fig. 1 - The Orang-Outan carrying off a Negro Girl Gravura de John Chapman a partir de desenho de Johann E. Ihle |Act directs (1795) 
Niccolò Bambini, Peter Paul Rubens, Giambattista Tieopolo e Jacques-Louis David, entre outros, abordaram em suas obras esses raptos famosos. Também escultores como Giambologna, Bernini, Girardon e Wilhelm Beyer talharam em pedra raptos de mulheres ou deusas.

No Salão de Pintura e Escultura de Paris, em 1859, o rapto foi tema de uma obra do escultor francês Emmanuel Frémiet. A escultura causou polêmica e a sua exibição foi autorizada com restrição para um público avisado. A representação de um gorila que carrega uma mulher desfalecida foi considerada um violo premeditado pelo poeta e crítico de arte Charles Baudelaire (Ducros, 1992, p. 270). Foi também Baudelaire quem traduziu para o francês o conto, The Murders in the Rue Morgue, do escritor norte-americano Edgar Allan Poe, publicado em Paris em 1856. Nesse conto, um orangotango comete um duplo assassinato. Tanto na novela de Poe quanto na escultura de Frémiet, atos como assassinato e violo de mulheres por grandes símios suscitavam especulações sobre a inteligência e as paixões desses primatas ${ }^{20}$.

Além dos famosos raptos de mulheres e deusas na mitologia, havia o "rapto ritual" na Antiguidade. Em 1864, no seu estudo clássico sobre o culto, o direito e as instituições da Grécia e de Roma, Fustel de Coulanges mencionou uma forma de "rapto ritual". Ao tratar do matrimônio como a primeira instituição da religião doméstica na Cidade Antiga, referiu-se ao rito de o marido carregar a mulher "simulando um rapto”. Depois de uma "luta simulada”, “o esposo ergue-a nos braços e fá-la atravessar a porta com todo o cuidado para que os pés da esposa não toquem a soleira" (Coulanges, 1975, p. 37).

Na segunda metade do século XIX, as hipóteses sobre as estratégias de reprodução de grupos humanos fazem recuar o rapto de mulheres para priscas eras (Vogt, 1863; Mac Lennan, 1865; Tylor, 1865; Darwin, 1871; Lubbock, 1871; Spencer, 1873; Morgan, 1877; Engels, 1884) ${ }^{21}$. Como as evidências de fósseis humanos concorriam para uma profunda revisão da "pré-história”, pode-se dizer que a aceitação de um tempo de milhões de anos favorecia a composição de sequências evolutivas, inclusive para a evolução humana ${ }^{22}$. Mas o evolucionismo encontrava ainda resistência para uma história da humanidade. De todo modo, era cada vez mais contestada a ideia da forma patriarcal de família, como se ela não tivesse tido evolução alguma através da história.

Alguns autores admitiam a ideia de uma promiscuidade sexual nos tempos primitivos. $\mathrm{O}$ rapto aparecia em várias etnografias, e as suas origens se confundiam com as primeiras formas de exogamia. Referindo-se à forma primitiva de casamentos na Austrália, Friedrich Engels (1884, p. 51) afirmou que "mesmo onde se pratica o rapto das mulheres, que com frequência é a regra em várias regiões, a lei das classes é cuidadosamente mantida" ${ }^{23}$. Para o filósofo alemão, no rapto das mulheres, encontravam-se já indícios da passagem à monogamia. Engels parece desconhecer o trabalho sobre a seleção sexual na evolução humana de Darwin (1871), ao menos não se refere a ele nenhuma vez em seu ensaio. Na sua obra $A$ origem da família, da propriedade privada e do Estado, Engels segue o caminho aberto por Lewis Henry Morgan sobre o sistema de parentesco dos iroqueses. Assim
20 Além da escultura do gorila que rapta uma mulher, Frémiet fez uma escultura de um orangotango que estrangula um homem. Essa escultura do primata homicida se encontra na entrada da galeria de paleontologia e anatomia comparada do Museu de História Natural de Paris.

21 Não raro a publicação de diferentes aportes científicos era feita por uma mesma editora. Para ficar num exemplo, a mesma editora nova-iorquina que publicou The Descendent of the Man, de Charles Darwin, era também a editora de The Origin of Civilization, de Sir John Lubbock, e The Philosophy of Evolution, de Herbert Spencer. 22 Segundo Faria (2012, p. 210), a ampliação da concepção do tempo geológico e, por conseguinte, da história natural pré-humana teve desdobramento na formulação de teorias evolutivas, como a teoria da seleção natural de Charles Darwin.

23 No original: Selbst wo Frauen geraubt werden, wie das häufig und in manchen Gegenden die Regel ist, wird das Klassengesetz sorgfältig eingehalten. 
como Karl Marx, Engels havia identificado no trabalho de Morgan uma concepção materialista da história ${ }^{24}$.

Apesar da concepção materialista da história não ser predominante na segunda metade do século XIX, ela integrava o debate científico sobre as sociedades primitivas e sua evolução nos períodos convencionalmente chamados de selvageria e barbárie e, por conseguinte, sobre o rapto de mulheres ${ }^{25}$. Entre as diferentes explicações sobre as origens da exogamia nos grupos humanos, o rapto era para alguns autores, como Mac Lennan, Lubbock e Spencer, um ato fundamentalmente violento.

Depois do escândalo de 1859, o escultor Frémiet voltaria ao tema do rapto numa nova escultura para o Salão dos Artistas de 1887. Como Emmanuel Frémiet frequentava o círculo intelectual do Museu Nacional de História Natural de Paris, provavelmente, ele teve conhecimento dessas novas interpretações sobre o rapto nas priscas eras da humanidade. Além de professor de desenho no MNHH, Frémiet era diretor do setor de esculturas do Museu do Louvre, o que lhe permitia conhecer as diferentes versões de raptos de mulheres ou deusas de um dos principais acervos museológicos da Europa.

Na escultura de Frémiet para o Salão de 1887, a mulher procura se livrar do gorila. O raptor carrega ainda em sua mão esquerda uma pedra lascada. Não há dúvida sobre a intenção do escultor de abordar o rapto sob um novo paradigma, em que cada ser não tem mais uma função a cumprir na natureza e sim deve lutar para viver. É também uma luta entre barbárie e civilização. Ao ressaltar a violência do rapto, o escultor parece intrigado com as teses sobre as origens da exogamia. $\mathrm{O}$ mesmo tema do rapto que causou polêmica no Salão de 1859 seria premiado em 1887, pois, dessa vez, o escultor francês recebeu a medalha de honra. A aceitação cada vez maior do evolucionismo na academia pode ser uma pista dessa mudança na forma de apreciar o tema do rapto proposto por Frémiet. Mas o gorila pode representar o retorno do recalcado, como se a natureza cobrasse o seu tributo à civilização.
24 Uma súmula do Ancient Society de L. H. Morgan feita por Marx foi publicada em russo em 1945. Engels possuía excertos detalhados que Marx retirou da obra de Morgan, como também anotações críticas do seu falecido amigo. Algumas delas foram reproduzidas em sua obra A origem da família, da propriedade privada e do Estado. Sobre o impacto da obra de Morgan no pensamento de Marx e Engels, cf. Álvares (2019).

25 Depois da primeira "interpretação materialista" de L. H. Morgan sobre o rapto entre os iroqueses, seguiram-se outras abordagens sobre a cultura e a sociedade dos iroqueses. Entre elas, destaco o aporte da etno-história do antropólogo canadense Roland Viau e que coloca no centro da análise a guerra de captura (Viaux, 2000). Para a história de um rapto entre os iroqueses, ver ainda o livro de John Demos (2009). 


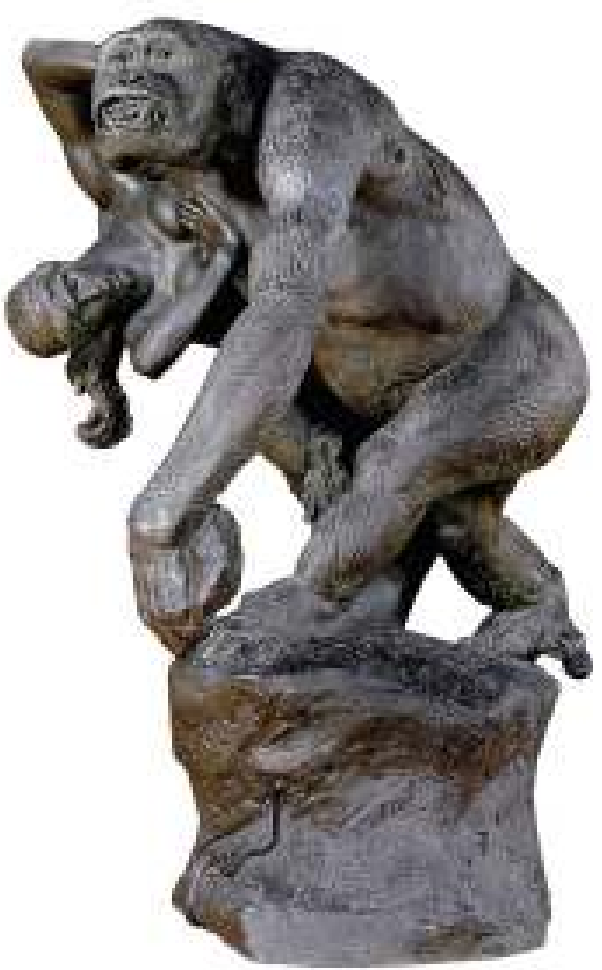

No último quartel do século XIX, o número de matérias ilustradas sobre os gorilas aumentou na imprensa periódica. Em 1878, o Journal des Voyages publicou em sua primeira página uma cena de um gorila a atacar três homens africanos, enquanto um outro gorila leva sobre o seu ombro uma jovem ${ }^{26}$. Em 1885, o mesmo periódico reproduziu o segundo capítulo de um romance de Louis-Henri Broussenard, no qual uma jovem foi raptada por um gorila. Uma ilustração da cena apareceu na primeira página do semanário francês ${ }^{27}$. Anos depois, outra matéria do mesmo periódico abordava uma expedição no país dos gorilas ${ }^{28}$. Em 1909, o Journal de Voyages publicou uma outra história de rapto de uma mulher por um gorila e com ilustração na primeira página ${ }^{29}$. Esses exemplos da imprensa metropolitana demonstram a inscrição das representações do gorila como raptor de mulheres no imaginário ocidental.

Como observou Frantz Fanon (1952, p. 121), essas aventuras da imprensa ilustrada, assim como os filmes de cinema, tinham impactos no imaginário das pessoas e concorriam para a alienação em contexto colonial. Para analisar a alienação e outros distúrbios decorrentes do racismo, Fanon recorreu à noção de catarse coletiva para tratar de uma literatura infanto-juvenil (de Tarzan, de exploradores etc.) cuja função era canalizar e liberar as energias agressivas coletivamente acumuladas (Fanon, 1952, p. 120-121). Algumas histórias e ilustrações de periódicos, como o Journal des Voyages, cumpriram com essa função de dar vazão à agressividade coletiva.

Para leitores ávidos de histórias fantásticas, a imprensa periódica ilustrada publicava aventuras na África com uma narrativa similar. Em geral, as selvas africanas escondiam tesouros que o aventureiro branco alcançaria após superar os
Fig. 2 - Gorille enlevant une femme (1887)

Emmanuel Frémiet

Musée des Beaux-Arts de Nantes
26 Chasses et aventures au pays des gorilles. Journal des Voyages et des aventures de terre et de mer, Paris, 3 février 1878, (Nr. 30)https://gallica.bnf. fr/ark:/12148/bpt6k6859232z/ f1.image [consultado em 20.10.2020].

27 Les aventures d'un gamin de Paris au pays des lions, Journal des Voyages et des aventures de terre et de mer, Paris, 10 mai 1885, (Nr. 409). https:/gallica.bnf.fr/ark:/12148/ bpt6k68596115/f1.image [consultado em 20.10.2020]. 28 Le docteur Garner chez les gorilles. Journal des Voyages et des aventures de terre et de mer, Paris, 14 février 1892 (Nr. 762). https://gallica.bnf.fr/ark:/12148/ bpt6k6863416z/f1.image [consultado em 20.10.2020].

29 Chez les gorilles, Journal des Voyages et des aventures de terre et de mer, Paris, 31 janvier 1909, (Nr. 635). https:// gallica.bnf.fr/ark:/12148/ bpt6k6864744m/f1.image [consultado em 20.10.2020]. 
obstáculos à sua frente, como ataques de animais selvagens e de tribos de canibais. Os primeiros filmes de Tarzan também se inscrevem nessa lógica. Nessas aventuras em África, a fixação maníaca na violência e na morte, além dos estereótipos sobre as populações africanas, permite questionar a relação da mesma com o recalque, com a censura sexual do público leitor ou espectador (Fanon, 1952, p. 122).

Nessa literatura e na imprensa periódica, o outro (o negro ou o selvagem) passaram a ser vistos como obstáculos e mesmo culpados pelos eventuais fracassos da aventura colonial. Tornava-se o outro um bode-expiatório num processo de catarse coletiva, como referiu-se Fanon ao tratar de um fenômeno (Racial Scapegoating) que concorreu para o mito do "Bad Indian" nos Estados Unidos (Hook, 2004, p. 120). O racismo canalizava uma agressividade coletiva e podia confundir o adversário original com o colonizado. Assim, o recalque original (Urverdrängung) podia voltar combinado com novas frustrações e/ou novas angústias.

\section{0 adversário "gorila"}

Desde os primeiros artigos sobre o gorila, a anatomia comparada aproximou o gorila do homem africano. O racismo científico dos meados do século XIX foi determinante para a classificação do gorila. Com a vulgarização das teorias raciais, não tardou para ocorrer a metamorfose do homem negro em gorila nas imagens satíricas da imprensa periódica ilustrada. Durante a Guerra de 1914-1918, o recrutamento de africanos para as tropas francesas e britânicas foi alvo das críticas dos semanários satíricos alemães. Sob o traço caricatural, as imagens de soldados africanos como gorilas, como canibais ou como monstros entre o humano e o bestial eram recorrentes na imprensa ilustrada alemã. Com a derrota do II Reich e a presença de soldados africanos nas zonas de ocupação na Alemanha, acirraram-se a crítica mordaz e as denúncias da "africanização" da Europa por meio de caricaturas de cariz racista (Correa, 2016a).

Em duas caricaturas publicadas entre final de maio e início de junho de 1920, os soldados africanos foram transformados em gorilas. Ambas as caricaturas foram inspiradas na escultura de Emmanuel Frémiet. Na revista berlinense Kladderadatsch, a caricatura intitulada "O terror negro nos territórios alemães" revela o racismo do período entre-guerras ${ }^{30}$. A mulher que o "gorila" carrega representa a região alemã sob ocupação das tropas francesas desde o final da guerra. Poucos dias depois, foi a vez do caricaturista norueguês Olaf Gulbransson desenhar um soldado das tropas coloniais como um gorila. Sob o título "A ocupação negra", a caricatura foi publicada na Simplicissismus, a principal revista satírica de Munique. Para o caricaturista, era "uma vergonha para a raça branca", conforme a legenda ${ }^{31}$. No mesmo ano, circulou o panfleto de Edmond Morel, intitulado Black Horror on the Rhine, no qual criticava o militarismo na Europa a partir de uma estranha combinação de pacifismo e racismo.

As caricaturas do soldado africano como gorila contêm um detalhe que esconde um paradoxo. Trata-se do sexo do gorila. Na primeira caricatura, a perna esquerda do gorila oculta o seu sexo, na segunda são os cabelos da vítima que
30 Der schwarze Terror in deutschen Landen (Frei nach "der Gorilla" von Frémiet), Kladderadatsch, Berlin, 30.05.1920, (Nr. 22). https://digi. ub.uni-heidelberg.de/diglit/ kla1920/0317/image [consultado em 20.10.2020].

31 Die schwarze Besatzung (nach Frémiet), Simplicissimus, München, 09.06.1920, (Nr. 11). http://www.simplicissimus.info/ [consultado em 20.10.2020]. 
escondem o órgão genital do raptador. Acontece que o imaginário colonial fez do gorila um monstro, um animal cuja lubricidade e ferocidade não tinham limites. O tamanho do sexo não podia contradizer todo o estereótipo em torno da imagem daquele que incarnava um animal libidinoso e depravado ${ }^{32}$. Curiosamente, nenhum dos dois desenhistas ousou mostrar um sexo desproporcional, mesmo sendo o exagero um apanágio da caricatura. Essa autocensura pode ter a ver com o complexo de Édipo ou de castração dos desenhistas ou com os ressentimentos dos homens alemães depois da derrota e das imposições do Tratado de Versalhes ou simplesmente com o respeito a um código vigente, já que mostrar o sexo masculino seria por demais obsceno para o público leitor.

Muitas foram as caricaturas sobre a ocupação da Renânia nas principais revistas satíricas alemãs durante a República de Weimar. Entre outras, tem-se o gorila sanguinário, representação animalesca do soldado africano a quem se atribuiam centenas de crimes entre assassinatos, estupros, roubos etc. ${ }^{33}$. Numa outra caricatura estampada na capa da revista Simplicissimus, o "gorila" tem por refém uma mulher. Dessa vez, ela é uma alegoria da Justiça ${ }^{34}$.

O deslocamento da representação de um soldado africano à figura de um gorila foi um recurso racista usado por alguns caricaturistas da imprensa satírica alemã. No contexto do colonialismo e das teorias raciais, a copiosa produção de caricaturas sobre a "africanização" da Europa acusava ainda o medo da miscigenação, da degeneração racial e de outras fantasias (Correa, 2016a). Na altura, a miscigenação era vista por muitos como uma degeneração (Wigger, 2010).

Com humor mordaz e sarcasmo, a imprensa satírica alemã abordou a propalada negrofilia dos franceses. A alegoria feminina da república francesa em companhia de um amante africano foi tema, por exemplo, na caricatura intitulada "A viúva alegre". Sob o lápis de Oskar Theodor Garvens, o africano recebeu feições simiescas ${ }^{35}$. Ao caricaturar as relações entre franceses e africanos através de uma ótica sexista e racista, os desenhistas colaboradores das revistas satíricas de Berlim e Munique se valeram de elementos da cultura popular mas também de algumas teorias científicas em voga. No período de 1870 a 1930, as teorias racistas, notadamente aquelas com base no poligenismo, persistiram no imaginário social, apesar da afirmação paulatina do evolucionismo darwinista no meio científico ${ }^{36}$.

A propalada "africanização" da Europa fez convergir negrofobia e antissemitismo. Em Mein Kampf, Adolf Hitler acusou os judeus de fomentar a degeneração da raça ariana através da "bastardização" à força pelas tropas africanas nas zonas de ocupação no Reno. Cabe atentar para a conexão que estabelece Frantz Fanon ao tratar da negrofobia e do antissemitismo na França, apontando para o perigo intelectual e o perigo biológico que representavam, respectivamente, o Judeu e o Negro, no imaginário social (Fanon, 1952, p. 136).

Curiosa combinação da figura do judeu com a do gorila ocorreu no plano literário. Em 1891, o antissemitismo está subjacente no romance Le Gorille, do francês Oscar Méténier, cujo monstro é um judeu. "Um gorila que tortura uma jovem mulher" (Méténier, 1891, p. 208). Vale o adendo que a ilustração da capa do romance é a imagem da famosa escultura do gorila carregando uma jovem,
32 Um gorila macho pode chegar a $200 \mathrm{~kg}$ e a $1 \mathrm{~m} 80 \mathrm{em}$ posição bípede, o que contrasta com o tamanho do seu pênis inferior a $5 \mathrm{~cm}$.

33 An das Weltgewissen, Simplicissimus, München, 05.02.1923, (Nr. 45), p. 629. http://www.simplicissimus.info/ [consultado em 20.10.2020].

34 Justitia im Ruhrgebiet, Simplicissimus, München, 28.05.1923, (Nr. 9), p. 105. http:// www.simplicissimus.info/ [consultado em 20.10.2020].

35 Die Lustige Witwe, Kladderadatsch, Berlin, 12.08.1923, (Nr. 32), p. 519. https://digi. ub.uni-heidelberg.de/diglit/ kla1923/0519/image [consultado em 25.10.2020].

36 A relação entre racismo popular e científico e projeto nacional tiveram um desenvolvimento similar no Brasil entre 1870 e 1930. Cientistas, juristas, médicos, literatos e viajantes estrangeiros e nacionais viram o Brasil como um grande laboratório racial (Schwarcz, 1993). O tempo decorrido da Lei do Ventre Livre (1871) à Lei Áurea (1888) coincide com a importação de teorias raciais pelos homens de ciência e letras do império brasileiro. Essas novas teorias raciais serviram para enquadrar populações consideradas racialmente inferiores. 
de Emmanuel Frémiet. Considerando o antissemitismo e o racismo à época dos impérios coloniais, pode-se melhor compreender como as versões do rapto de mulher pelo gorila impactavam a sociedade metropolitana e a sua moral burguesa.

A imagem do judeu ou do negro como gorila pode ser compreendida pela necessidade de encontrar entre os macacos antropoides, entre os negros e mesmo entre os judeus, a figura mitológica dos sátiros (Mannoni apud Fanon, 1952, p. 136). As fantasiosas imagens do "gorila judeu" ou do "gorila negro" derivam, outrossim, da tríade ansiedade/perigo/desamparo. Se o judeu representa uma ameaça intelectual, o negro representa o perigo biológico. Ter fobia do negro é ter medo do biológico, afirmou Fanon (1952, p. 136), que acrescentou que o homem negro era visto como um concorrente sexual pelo homem branco.

A acurada observação de Fanon serve também como pista para a análise de muitas caricaturas na imprensa satírica alemã que evidenciam uma negrofobia (Correa, 2016a). A fobia está, geralmente, relacionada a animais (Freud, 1912, p. 412). Assim, a negrofobia pressupõe a animalização do negro. Durante as primeiras décadas do século XX, o propalado "perigo negro" motivou uma série de imagens satíricas, na qual a metamorfose do negro em gorila foi um indicativo do racismo à época dos impérios coloniais.

A suposta vantagem sexual do homem negro era uma fantasia com efeitos reais, pois um conjunto de normas e sanções era aplicada em decorrência do racismo na sociedade colonial. A presença de homens negros nas metrópoles era, igualmente, tema de caricaturas na imprensa periódica ilustrada. Um conjunto delas aborda com humor mordaz, e mesmo com sarcasmo, a presença de homens negros entre mulheres brancas. Não raro, os caricaturistas misturavam racismo com machismo, ao criticar a presença de supostos concorrentes negros e a liberdade sexual da mulher moderna ${ }^{37}$. Assim como na imprensa satírica alemã, as caricaturas nos semanários ilustrados franceses trataram o flerte de mulheres brancas e homens negros com derrisão e não raro associadas ao decadentismo fin-de-siècle $e^{38}$.

As imagens satíricas sobre mulheres brancas e homens negros foram produzidas por homens brancos. Muitas delas tinham por público-alvo leitores metropolitanos, mas também leitores nas colônias. No semanário Les Echos d'Afrique noire de Dacar, uma caricatura mostra um estudante da África Ocidental Francesa a gastar a sua bolsa de estudos com mulheres em Paris ${ }^{39}$. A imagem satírica de Grum se afinava ao discurso do redator-chefe do jornal, Maurice Voisin, para quem os recursos públicos eram usados indevidamente, como ilustra o bolsista de vida mundana na metrópole.
37 Diante do grande número de caricaturas sobre essa temática, seguem apenas a referência de alguns exemplos de um semanário satírico alemão: Was uns not thut. Simplicissimus 14.01.1899 (Nr. 42), p. 329; Tête-à-tête. Simplicissimus, 26.11.1900 (Nr. 35), p. 280; Attraktion, Simplicissimus, 06.05.1912 ( $\mathrm{Nr}$. 6), p. 95; Zwischen den Rassen, Simplicissimus, 30.07.1928 (Nr. 18), p. 238. http://www. simplicissimus.info/ [consultado em 20.10.2020].

38 Ver por exemplo os desenhos de capa: Le Rire, 19 Mai 1900, (N. 289), p. 1; Le Rire, 25 Août 1900, (N. 303), p. 1, respectivamente https://gallica.bnf. fr/ark:/12148/bpt6k11731953. item e https://gallica.bnf.fr/ ark:/12148/bpt6k1173209p.item [consultado em 20.10.2020].

39 Les Echos d'Afrique noire, du 3 au 9 décembre 1948, Nr. 92, (Bibliothèque IFAN/UCAD, Dakar). 


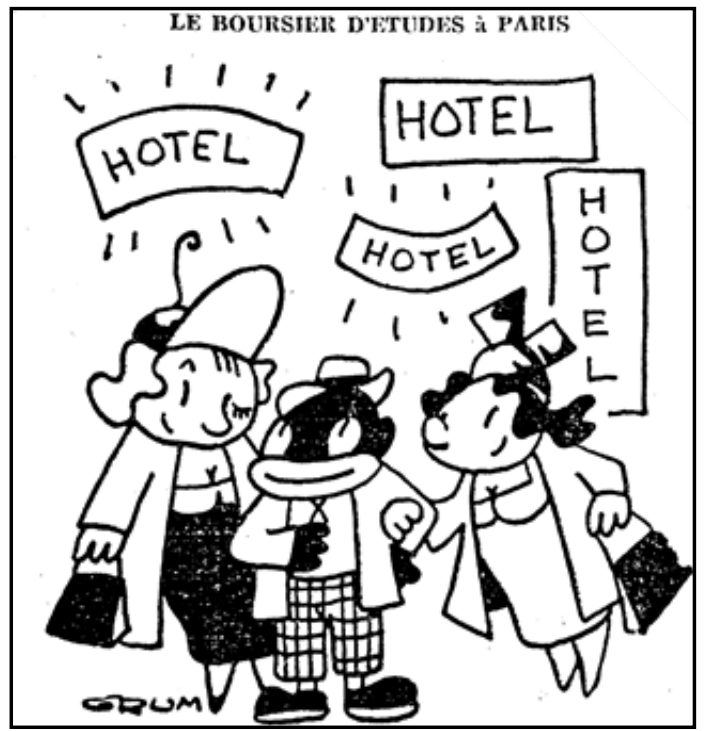

Em 1946, as casas de prostituição na França foram fechadas após uma lei proposta à Assembleia Nacional por um deputado do Partido Comunista. Devido ao déficit habitacional do pós-guerra, o ministro da Educação requisitou algumas delas para abrigar estudantes. Bolsistas da AOF e de outros territórios da chamada União Francesa encontravam uma locação acessível nessas novas residências estudantis. O próprio Frantz Fanon alugou um quarto numa antiga casa de prostituição em Lyon (Macey, 2013, p. 138). Ele mesmo se referiu ao "rito de iniciação" de imigrantes afro-caribenhos ao chegar à França. Em conversa com Antilhanos, soube que a preocupação mais constante deles era fazer sexo com uma mulher branca. Ao chegar no Havre, eles se dirigiam aos prostíbulos. Uma vez cumprido com esse "rito de iniciação", eles tomavam o trem para Paris (Fanon, 1952, p. 60).

Fanon chamou também atenção para as fantasias de mulheres brancas em torno do estupro. Com sarcasmo apontou: "quem diz estupro, diz negro" (Fanon, 1952, p. 136). Em termos literários, Doris Lessing (1950) descreveu a tensão e as fantasias de uma mulher branca diante de um homem negro em situação colonial. Na nova historiografia do colonialismo têm sido abordadas outras facetas da violência sexual à época da chamada Partilha da África. O próprio continente serviu de alegoria feminina para uma penetração violenta ${ }^{40}$.

$\mathrm{Na}$ imprensa ilustrada, caricaturas de regiões africanas em alegorias femininas foram muito recorrentes nesse período entre 1880 e 1910. Nessas imagens satíricas, a África era um objeto do desejo masculino, um mero alvo das disputas entre potências imperiais representadas por homens brancos (Correa, 2016b, p. 206). Essa versão de uma "seleção sexual" da Partilha da África serve de pista para supor o que camufla ou esconde a fantasia do gorila que rapta mulheres. Afinal, a África bem poderia ser a alegoria da mulher raptada e violada por "gorilas brancos”. No plano figurado, a Partilha da África teria sido um estupro coletivo.

Mas não foi somente a África que serviu de alegoria feminina ao rapto. A Grécia aparece como a vítima do "gorila" John Bull numa caricatura de Wilhelm Anton Wellner ${ }^{41}$. Também a Liberdade aparece como uma mulher raptada nos braços do "gorila" Guilherme II num cartaz do artista gráfico Harry Ryle Hopps para uma
Fig. 3 - Bolsista em Paris Les Echos d'Afrique noire, 1948 Bibliothèque IFAN/Dacar
40 Na introdução do seu livro Couro Imperial, Anne McClintock (1995) tratou da alegoria feminina da África a partir de um mapa ficcional na obra As Minas do Rei Salomão, do escritor vitoriano Henry Rider Haggard.

41 Das Opfer (nach Frémiet) Lustige Blätter: schönstes buntes Witzblatt Deutschlands, (Kriegs-Nummer 78), Berlin, 1916, p. 16. https://digi. ub.uni-heidelberg.de/diglit/ lb31/0087/image [consultado em 20.10.2020]. 
campanha de alistamento militar nos Estados-Unidos durante a Primeira Grande Guerra. Tem-se ainda a Renânia raptada pelo "gorila” Clemenceau numa caricatura intitulada "Vencedor e Vencida", na primeira página de uma revista satírica alemã ${ }^{42}$. Em 1939, o desenhista inglês Bernard Partridge fez de Hitler um gorila que rapta a Liberdade numa caricatura publicada na Punch Magazine ${ }^{43}$. Todas essas imagens se inspiraram na escultura de Frémiet. A imagem do gorila e da sua vítima feminina descolou-se da escultura de Frémiet e ganhou novas versões nem sempre deliberadas como na fotografia da modelo Gisele Bündchen e a estrela do basquetebol LeBron James para a capa da edição nova-iorquina da revista Vogue de abril de 2008. Essa polêmica versão da "bela e a fera" não deixa de ser uma evidência das "múltiplas vidas" de uma imagem ${ }^{44}$.

Uma vez integrada ao imaginário social, a imagem do gorila como um monstro entre o humano e o bestial foi recorrente entre escritores, artistas plásticos e artistas gráficos. Além dos romances e da imprensa periódica ilustrada, as fantasias em torno do gorila ganharam a forma de imagem em movimento nos filmes de cinema, o que teve um desdobramento no "inconsciente ótico" moderno ${ }^{45}$.

\section{Imagens decalcadas}

Desde a polêmica da primeira versão da escultura do gorila de Frémiet em 1859 até a estreia dos filmes Ingagi e King Kong, respectivamente em 1930 e 1933, houve uma repetição da fantasia sexual em torno do gorila que rapta mulheres. Essa persistência do gorila como uma figura poderosa, cuja lubricidade não conhece os freios da civilização, indica um sintoma social latente ou manifesto durante o período de consolidação das teorias raciais e da dominação colonial em África.

A hipersexualização do gorila se confundia com aquela do homem negro. A amálgama de ambas as representações teve por liga o mito de uma pulsão libidinal desenfreada, o que representava a antítese da moral sexual "civilizada" ${ }^{46}$. Essas imagens decalcadas no imaginário ocidental tinham forte apelo nas primeiras décadas do século XX. Carl Ethan Akeley, um taxidermista norte-americano e um dos primeiros a estudar os gorilas em seu próprio habitat, procurou desfazer o mito em torno do gorila raptor de mulheres. Para reabilitar o grande primata, Akeley criticou a escultura de Frémiet que havia consagrado o mito do animal hipersexualizado (Jones, 2006, p. 326).

Apesar dos esforços de alguns estudiosos para desfazer os mitos em torno do gorila, a indústria cinematográfica nos Estados Unidos explora o filão numa sociedade estruturada pelo racismo. Entre 1928 e 1958, o ator filipino Charles Gemora fez dezenas de papéis de gorila em filmes da indústria cinematográfica norte-americana. Destaca-se, entre outros, o filme Ingagi (1930), por abordar o intercurso sexual entre um gorila e uma mulher. Ainda em 1932, esse filme estava em cartaz em Lisboa ${ }^{47}$. Trata-se de um primeiro registro cinematográfico do gorila raptor de mulheres.
42 Sieger und Besiegte (nach Frémiet). Der Wahre Jacob, Stuttgart, 3.07.1919 (Nr. 860). http://www.der-wahre-jacob. de/ [consultado em 20.10.2020] 43 John Bull's War Aim (Bernard Partridge after Emmanuel Frémiet), Punch Magazine, 18 octobre 1939. https://www. punch.co.uk/ [consultado em 20.10.2020].

44 Agradeço ao Francisco Miguel pela informação sobre a polêmica em torno dessa capa de Vogue.

45 Em seus ensaios Pequena História da Fotografia (1931) e A obra de arte na era de sua reprodutibilidade técnica (1935), Walter Benjamin chamou atenção para a relação do potencial da fotografia e do cinema com o "inconsciente ótico" na modernidade.

46 Freud (1908) relacionou a moral sexual "civilizada" com a nervosidade moderna.

47 O Século, Lisboa, 12 de novembro de 1932, p. 3 (Hemeroteca Municipal de Lisboa). 


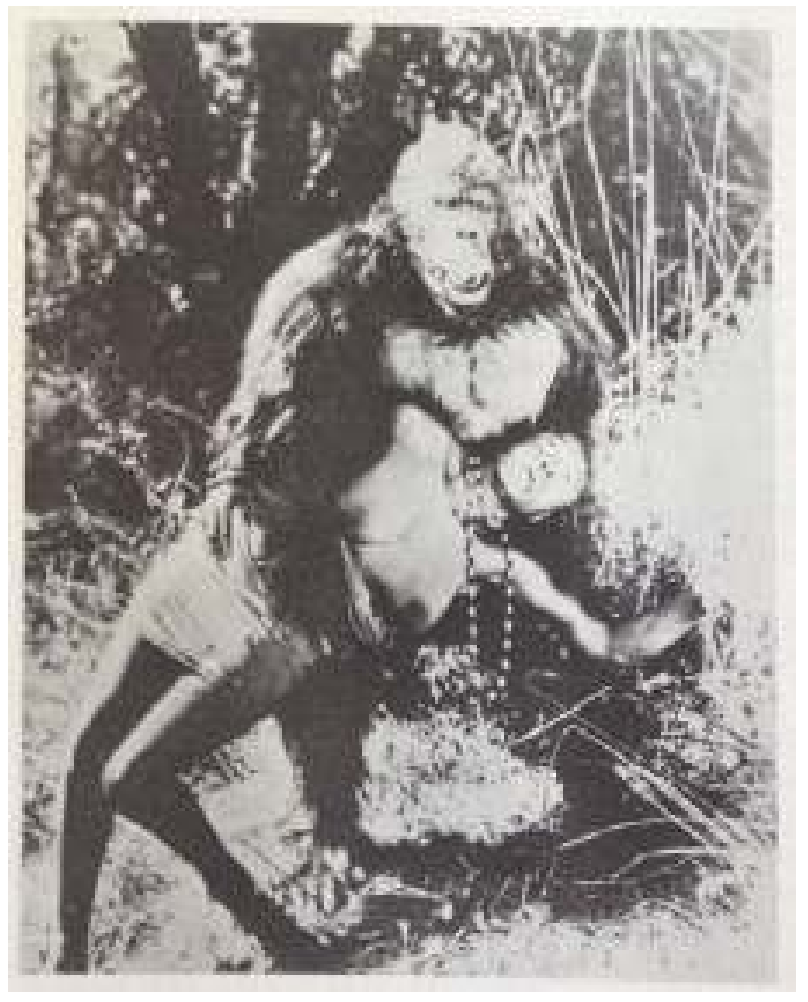

Em 1933, houve a estreia de King Kong no cinema, cujo cartaz remete à figura icônica do rapto da escultura de Frémiet. Desde então, a fantasia em torno do gorila que sequestra mulheres se tornou uma constante no cinema. A propósito, o rapto de Jane em Tarzan The Ape Man (1932) remete ao mesmo imaginário social. Em 1950, gorilas que atacam mulheres aparecem no terceiro filme da série Jungle Jim. Em 1958, o filme Bride of the Gorilla chegou às telas do cinema. Nesses filmes, percebe-se a ambivalência da representação de raça, gênero e monstruosidades em contexto colonial na indústria cinematográfica (Berenstein, 1994).

O intercurso sexual entre uma mulher e um gorila foi, igualmente, constante numa literatura popular e mesmo nas bandas desenhadas. A novela científica de Pinto Guimarães, intitulada O filho do gorila, narra o "sacrifício" da jovem Martha, que serviu de cobaia humana para uma experiência antropológica. Ela fica grávida de um gorila, o que prova não ser uma fantasia a hipótese do seu noivo. Por meio dessa experiência, o jovem cientista conseguiu "ter provada a afirmação científica de que o homem descende do macaco" (Guimarães, 1937, p. 29).
Fig. 4 - Ingagi (1930)

Centro de Documentação da Cinemateca Portuguesa/Lisboa 


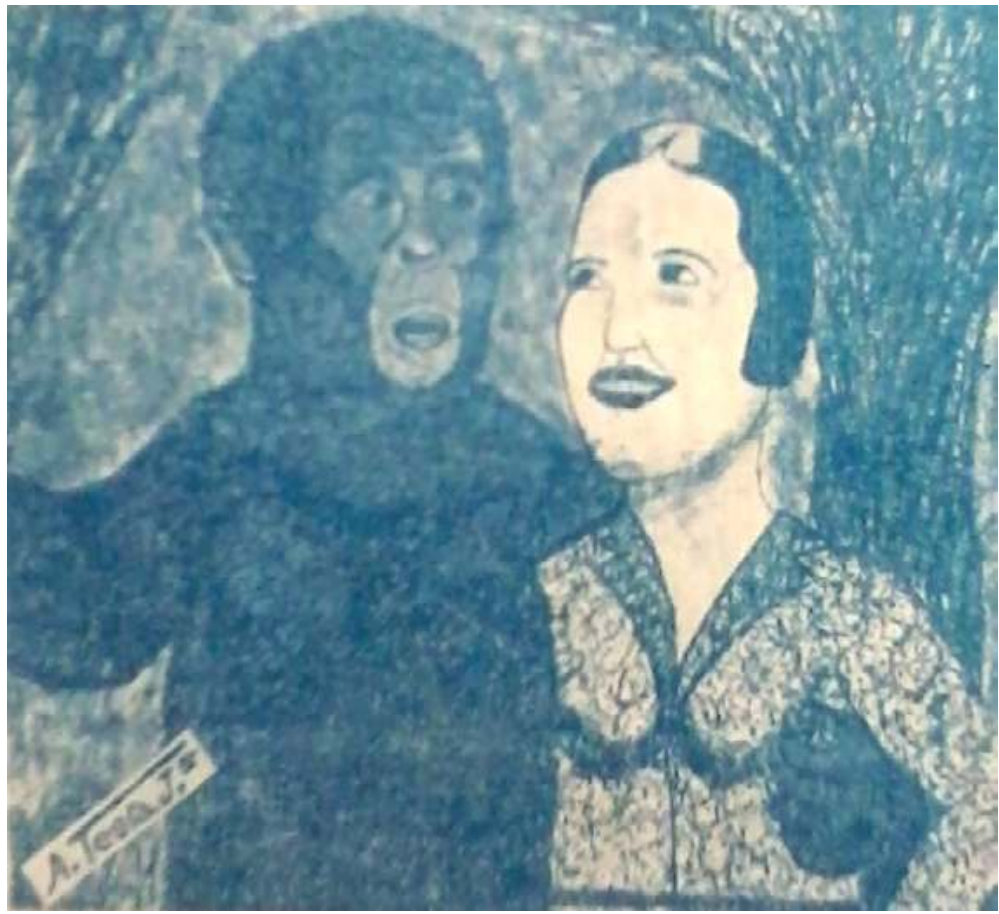

Outra mulher grávida de um gorila aparece no primeiro episódio de Animal City, do desenhista nigeriano Olufemi Olaide K. Arowolo (2002). A história dessa banda desenhada faz eco a uma tradição oral africana. Uma jovem encontra um gorila na floresta. $\mathrm{O}$ marido vem a seu socorro, mas ele é morto pelo gorila. $\mathrm{Na}$ verdade, trata-se de um gorila "possuído" (the evil forest), raptor e homicida ${ }^{48}$. Meses depois, a jovem Maya dará luz a gêmeos. Um deles é um gorila ${ }^{49}$.

A imagem de gorilas assassinos que "matavam porque estavam treinados para matar" apareceu com contornos de horror e ficção científica tanto no romance Congo quanto no filme homólogo ${ }^{50}$. Essas imagens decalcadas - da literatura popular à banda desenhada, da fotografia ao cinema - circulam por diferentes tempos e espaços. Segundo Cooper (2016, p. 179),

pedaços de imagens são retirados do seu contexto, tornando-se ainda mais atraentes devido às associações distantes que evocam. 0 imaginário de Hollywood influencia as populações no mato africano; o exotismo tropical é vendido no Faubourg de St. Honoré.

Esses circuitos sociais das imagens podem ser articulados para um estudo de cultura visual desde que os diferentes significados sejam contextualizados, pois essas imagens são, geralmente, decalcadas de seus contextos originais.

$\mathrm{O}$ racismo intrínseco em algumas fantasias em torno do gorila não impediu certas apropriações controversas. Alguns africanos chegaram a jogar com os códigos racistas numa espetacularização do corpo masculino, em performances que combinavam estereótipos de um colonialismo tardio. Foi o caso do Gorilla Ceasar, que exibia a sua força em espetáculos por Moçambique em novembro de 197351. Também um bailarino sob o nome artístico de King Kong fazia shows de "folclore africano" em recintos de diversão noturna de Lourenço Marques ${ }^{52}$. No
Fig. 5 - Ilustração de capa da novela $O$ filho do gorila, de Pinto Guimarães (1937) Biblioteca Nacional de Portugal

48 Segundo Patrick Mouguiama-Daouda (2007, p. 83), "os gorilas que matam são homens que se transformam e tomaram a aparência do primata". Ver também os depoimentos recolhidos por Takanori Oishi (2013).

49 http://www.africacomics. net/comics/animal-city-episode-one/ (consultado em 06.08.2020)

50 A adaptação do livro Congo de Michael Crichton (1980) para o cinema foi feita por Frank Marshall em 1995.

51 Gorilla Ceaser. Força bruta num homem inofensivo. Voz Africana. Beira, 6 de novembro de 1973, p. 8-9 (Hemeroteca Municipal de Lisboa).

52 King Kong é cartaz numa casa de espetáculos. Voz Africana. Beira, 4 de maio de 1974, p.10 (Hemeroteca Municipal de Lisboa). 
Brasil, outros apodos racistas aproximaram o homem negro e o gorila. No jardim zoológico de Belo Horizonte, havia o gorila chamado Idi Amin, nome imputado do presidente de Uganda entre 1971 e 197953. Já o ex-boxeador brasileiro Adilson Rodrigues era conhecido pelo nome de Maguila, uma referência ao gorila de um desenho animado de Hanna e Barbera.

Esses apelidos racistas insinuam atributos em comum entre homens negros e gorilas e se inscrevem no mesmo imaginário social que produziu as fantasias em torno da lubricidade do gorila e da hipersexualização do homem negro. Resta saber como algumas fantasias continuam a circular no imaginário social contemporâneo como imagens decalcadas do seu contexto original.

\section{Considerações finais}

As teorias raciais predominaram entre 1870 e 1930. Elas elaboraram comparações entre os primatas e hierarquias entre os grupos humanos. Delas decorrem algumas fantasias em torno do gorila. Outras teorias foram elaboradas nesse mesmo período. A poligamia entre os gorilas e o "despotismo" do macho-alfa inspiraram Freud desde os seus preparativos à redação de Totem e Tabu, publicado entre 1912 e 1913, ensaio que Thomas Mann (1929) considerou uma obra-prima da literatura alemã. Além da sua qualidade literária, Totem e Tabu apresenta um mito moderno da passagem da natureza à civilização. Paradoxalmente, o autor recorreu à estrutura filogenética da evolução humana proposta por Charles Darwin, mesmo que o autor de The descent of man (1871) tivesse considerado a evolução humana sem qualquer ruptura entre um estágio biológico e um cultural ou entre natureza e civilização. Além do darwinismo enfatizar a variação no processo evolutivo, o "efeito reverso da evolução" teve supina importância para a história da humanidade ${ }^{54}$.

Na década de 1950, encontram-se na seara no meio intelectual novas teses que contribuíram para superar os cânones em voga, como, por exemplo, o pensamento anticolonial de Frantz Fanon (1952), a antropologia estrutural de Lévi-Strauss (1952) e a filosofia libertária de Herbert Marcuse (1955) e Hannah Arendt (1958). Das ciências sociais e humanas, um importante arsenal muniu os projetos de emancipação. Contudo, as frustrações e as insatisfações de certos grupos sociais continuaram a produzir novas fantasias com rasgos racistas e com imprevisíveis desdobramentos no imaginário pós-colonial. A polissemia em torno do gorila seguiu um curso inusitado. Desde meados do século XX, o "gorilismo" foi um neologismo que prosperou na América Latina. $\mathrm{O}$ termo era usado pejorativamente por intelectuais de esquerda para adversários políticos, regimes autoritários e ditaduras. Além do "gorilismo militar", houve a variante "gorilismo crioulo" (Cueva, 1983).

No plano literário, a similaridade entre os grandes primatas deu azo para novos romances. Títulos de ficção literária como Les animaux dénaturés (1952), de Vercors, La Planète des Singes (1963), de Pierre Boulle, Congo (1980), de Michael Crichton, e The Woman and the Ape (1996), de Peter Høeg, exploram essas fronteiras entre o humano e o macaco e as ameaças para ambos na transgressão do liame
53 Idi Amin, o mais longevo gorila em cativeiro da América Latina, morreu com 38 anos em 2012. Depois da taxidermia, o corpo "naturalizado" do gorila teve uma "nova" vida no Museu de História Natural da PUC de Minas Gerais.

54 Embora não seja um conceito de Darwin, o efeito reverso da evolução serve para Patrick Tort (2008, p. 75-113) elucidar um importante aspecto do darwinismo. 
entre eles.

O jogo narrativo de aproximação entre sexualidade humana e sexualidade dos grandes símios tem uma longa tradição e continua a produzir fantasias na literatura, no cinema e mesmo em exposições. A imagem de um gorila antropomorfizado no cartaz da exposição Bêtes de Sexe, realizada em Paris entre outubro de 2012 e agosto de 2013, é um exemplo entre tantos outros de uma oscilação da figura do gorila entre o humano e o bestial. O que chama a atenção não é apenas o jogo de palavras do título em francês, mas o seu subtítulo: "La séduction dans le monde animal" 5 . Escusado é lembrar que, ao tratar da seleção sexual, Charles Darwin (1871) não usou o termo sedução. A sedução nunca é da ordem da natureza, ela é da ordem do artifício, afirma Jean Baudrillard (1979). Porém, a exposição supracitada fomentou um argumento falacioso ao antropomorfizar a sexualidade de outros animais e ao formular perigosas naturalizações (Miguel, 2014, p. 117). No que concerne ao gorila, mais uma vez, reproduziu-se o estereótipo do "animal sexual”, que, na verdade, raramente pratica o sexo e cuja seleção sexual pouco apresenta em termos de performance.

Malgrado um eventual processo de "dessublimação repressiva" (Marcuse, 1955), as imagens fantasiosas em torno do gorila persistem na cultura visual, o que deixa sugerir uma relação entre elas e uma provável patologia social que subjaz na contemporaneidade. Essas fantasias sexuais em torno do gorila e do liame entre o humano e o bestial tiveram ligação com o racismo do período dos impérios coloniais quando as metrópoles construíram uma imagem de si a partir de sua relações com as colônias. Se as "neuroses sociais" ou a "patologia das comunidades culturais" (Freud, 1937, p.269) esperam por uma teorização, ao menos, pode-se suspeitar que a figura do gorila fantasmagórico ou sua polissemia encobre uma ansiedade neurótica que, por sua vez, advém de uma cultura repressiva.

\section{Agradecimento}

O presente artigo é resultado parcial de pesquisas financiadas pelo Conselho Nacional de Desenvolvimento Científico e Tecnológico (CNPq), processo ${ }^{\circ}$ 312449/2017-8] e pela CAPES, processo $n^{\circ} 88881.171249 / 2018-01$. Agradecimento aos organizadores do dossiê temático Francisco Miguel e Nelson Mugabe, à editora Soraya Fleischer e especialmente às duas pessoas avaliadoras externas em sistema de duplo-anonimato, cujas sugestões foram de grande valia para a versão final do presente artigo.
55 Em francês, a expressão "bête de scène" é muito corrente para se referir a um artista capaz de promover a êxtase do público. A expressão sugere que a performance do artista tem quase um poder mágico sobre o público. 


\section{Referências}

ÁLVARES, Lucas Parreira. Flechas e Martelos: Marx e Engels como leitores de Lewis Morgan. Dissertação (Mestrado em Direito) - Universidade Federal de Minas Gerais, Belo Horizonte, 2019.

ARENDT, Hannah. The Origins of Totalitarianism. New York: Schocken Books.1951.

AROWOLO, Olufemi O. Animal City. In: FEDERICI, Sandra; REGGIANI, Andrea (Eds.) Africa Comics. Antologia delle migliori storie a fumetti del Premio Africa e Mediterraneo. Bologna: Lai-Momo, 2002.

BATES, A. W. Dr Kahn's Museum: obscene anatomy in Victorian London. Journal of the Royal Society of Medicine, v. 99, n. 12, p. 618-624, 2006.

COOPER, Frederick; STOLER, Ann Laura. Between Metropole and Colony. Rethinking a Research Agenda. In: Tension of Empire. Colonial Cultures in a Bourgeois World. Berkeley: University of California Press, p. 1-56, 1997.

CORREA, Sílvio Marcus de Souza. L'africanisation de l'Europe par la presse illustrée de l'Allemagne. In: DE GEMEAUX, Christine; REPUSSARD Catherine (Eds.). «Civiliser »le monde; "Ensauvager » l'Europe? Circulation des savoirs, transferts et Mimicry dans l'espace germanophone et sa sphère coloniale. Paris: Editions le Manuscrit, 2016a. p. 333-361.

CORREA, Sílvio M. de S. Caricatura de África: a Partilha da África pela imprensa ilustrada de Lisboa. Revista Outros Tempos, v. 13, n.22, p. 192-207, 2016 b.

CORREA, Sílvio M. de S. As partes do gorila e a "partilha da África". In: RIBEIRO, Alexandre; GEBARA, Alexsander; BERTHET, Marina (Orgs.). África: histórias conectadas. Niterói: Editora da UFF, 2015a. p. 133-146.

CORREA, Sílvio Marcus de Souza. A "Partilha do Gorila” entre ciência e literatura de alhures e saberes locais. História. Questões e Debates, v. 62, p. 107-132, 2015 b.

CORREA, Sílvio Marcus de Souza. Cultura e Natureza na "África Alemã”. Tempos históricos. Revista do Programa de Pós-Graduação em História da Unioeste, v. 15, p. 363-381, 2011.

CORREA, Sílvio Marcus de Souza. A antropofagia na África equatorial: etno-história e a realidade do(s) discurso(s) sobre o real. Afro-Ásia, n. 37, p. 9-41, 2008.

BAUDRILLARD, Jean. La séduction. Paris: Galilée, 1979.

BLANCHARD, Pascal et al. (dir.). Zoos Humains. Paris: La Découverte, 2002.

CASTELNAU, Francis. Renseignements sur l'Afrique centrale et sur une nation d'hommes à queue qui s'y trouveraient: d'après le rapport des nègres du Soudan, esclaves à Bahia. Paris: Bertrand, 1851.

CHAILLU, Pau B. Voyage Explorations and Adventures in Equatorial Africa. London: J. Murray, 1861.

CHAILLU, Paul B. Stories of the Gorilla Country. New York: Harper \& Brothers, 1867.

CHAILLU, Paul B. Equatorial Africa, with an account of the Race of Pigmies. American Geographical and Statistical Society Journal, v. 2, p. 99-112, 1870.

COOPER, Frederick. Histórias de África. Capitalismo, modernidade e globalização. Lisboa: Edições 70, 2016.

COOPER, Frederick; STOLER, Ann Laura. Tensions of Empire: Colonial Cultures in a Bour- 
Sílvio Marcus de Souza Correa

geois World. Berkeley: University of California Press, 1997.

COURET, Louis. Voyage au pays des Niam-Niams. Paris: Martinon, 1854.

CRICHTON, Michael. Congo. New York: Alfred A. Knopf, 1980.

CUEVA, Agustín. O desenvolvimento do capitalismo na América Latina. São Paulo: Global, 1983.

DARWIN, Charles. The descent of man, and selection in relation to sex. New York: D. Appleton, 1871.

DAPPER, Olfert. Description de l'Afrique. In: Objets interdits. Paris: Fondation Dapper, 1989 [1686].

DEMOS, John. Une captive heureuse chez les Iroquois. Histoire d'une famille de Nouvelle-Angleterre au début du XVIIle siècle. Laval: Presses de l'Université Laval, 2009.

DUCROS, Albert; DUCROS, Jacqueline. Gare au gorille: l'audace de Frémiet. Bulletins et Mémoires de la Société d'anthropologie de Paris, n. 3-4, p. 269-272, 1992.

DURKHEIM, Emile. La prohibition de l'inceste et ses origines. Année sociologique, 18961897, v. I, p. 1-70, 1897.

ENGELS, Friedrich. Der Ursprung der Familie, des Privateigentums und des Staats. Im Anschluß an Lewis H. Morgans Forschungen. Hottingen-Zürich: Verlag der Schweizerischen Volksbuchlandung, 1884.

EPPRECHT, Marc. The Making of "African Sexuality”: Early Sources, Current Debates. History Compass, v. 8, issue 8, p. 768-779, 2010.

EPPRECHT, Marc. Sexuality, Africa, History. The American Historical Review, v. 114, Issue 5, p. 1258-1272, 2009.

FANON, Frantz. Peau noire, masques blancs. Paris: Seuil, 1952.

FARIA, Felipe. Georges Cuvier: do estudo dos fósseis à paleontologia. São Paulo: Editora 34, 2012.

FOUCAULT, Michel. Les mots et les choses. Une archéologie des sciences humaines. Paris: Gallimard, 1966.

FREUD, Sigmund.. Konstruktionen in der Analyse. In: Studienausgabe. Bd. X, 2000. Frankfurt: Fischer Verlag, 1937. p. 393-406.

FREUD, Sigmund. Das Unbehagen in der Kultur. In: Studienausgabe. Bd. IX, Frankfurt: Fischer Verlag, 2000 [1937]. p. 191-270.

FREUD, Sigmund. Hemmung, Symptom und Angst. In: Studienausgabe. Bd. VI, Frankfurt: Fischer Verlag, 2000 [1926]. p. 227-310.

FREUD, Sigmund. Der Untergang des Ödipuskomplexes. Bd. V, Frankfurt: Fischer Verlag, 2000 [1924]. p. 243-251.

FREUD, Sigmund. Massenpsychologie und Ich-Analyse. In: Studienausgabe. Bd. IX, Frankfurt: Fischer Verlag, 2000 [1921]. p. 61-134.

FREUD, Sigmund. Aus der Geschichte einer infantilen Neurose. In: Studienausgabe. Bd. VIII, Frankfurt: Fischer Verlag, 2000 [1921]. p. 125-234.

FREUD, Sigmund. Psychopathologie des Alltagslebens. Berlin: S. Karger, 1917.

FREUD, Sigmund. Die Verdrängung. In: Studienausgabe. Bd. III, Frankfurt: Fischer Verlag, 2000 [1915]. p. 103-118.

FREUD, Sigmund. Totem und Tabu. In: Studienausgabe. Bd. IX, Frankfurt: Fischer Verlag, 2000 [1912]. p. 287-444. 
FREUD, Sigmund. Eine Kindheitserinnerung des Leonardo da Vinci. In: Studienausgabe. Bd. X, Frankfurt: Fischer Verlag, 2000 [1910]. p. 87-159.

FREUD, Sigmund. Die ,kulturelle' Sexualmoral und die moderne Nervosität. In: Studienausgabe. Bd. IX, Frankfurt: Fischer Verlag, 2000 [1908]. p. 9-32.

FREUD, Sigmund. Der Dichter und das Phantasien. In: Studienausgabe. Ergänzungsband. Frankfurt: Fischer Verlag, 2000 [1908]. p. 169-180.

FROSH, Stephen. Psychoanalysis, colonialism, racism. Journal of Theoretical and Philosophical Psychology, v. 33, n. 3, p. 141-154, 2013.

FUSTEL DE COULANGES, Numa D. A Cidade Antiga. Estudos sobre o culto, o direito, as instituições da Grécia e de Roma. São Paulo: Hemus, 1975.

GAY, Peter. Freud para historiadores. Rio de Janeiro: Paz e Terra, 1989.

GILES-VERNICK, Tamara; RUPP, Stephanie. Visions of apes, reflections on change: telling tales of great apes in equatorial Africa. African Studies Review, n. 49, p. 51-73, 2006.

GOULVEN, Laurent. La naissance du transformisme: Lamarck entre Linné et Darwin. Paris: Vuibert, 2001.

GUIMARÃES, Pinto. O filho do gorila. Setubal: Tip. A. Candido Guerreiro, 1937.

HOOK, Derek. Fanon and the psychoanalysis of racism. In: HOOK, D. (Ed.). Critical psychology. Lansdowne: Juta Academic Publishing, 2004. p. 114-137.

INGHAM, John. The Oedipus complex and the Signifying Chain: A View from Anthropology. Psychoanalysis Culture \& Society, n. 4, p. 50-62, 1999.

JONES, Jeannette Eileen. "Gorilla Trails in Paradise": Carl Akeley, Mary Bradley, and the American Search for the Missing Link. The Journal of American Culture, v. 29, n. 3, p. 321-336, 2006.

LUBBOCK, Sir John. The Origin of Civilisation and the primitive Condition of Man. New York: Appleton and Co., 1871.

LYONS, Andrew; LYONS, Harriet. Irregular Connections: a history of Anthropology and Sexuality (A. P. Lyons ; H. D. Lyons, Eds.). London: University of Nebrasca Press, 2004.

HØEG, Peter. The Woman and the Ape. New York: Farrar, Straus \& Giroux, 1996.

LESSING, Doris. The Grass is Singing. New York: Thomas Y. Crowell Co., 1950.

LÉVY-BRUHL, Lucien. Les fonctions mentales dans les sociétés inférieures. Paris: Alcan, 1910.

LEVI-STRAUSS, Claude. Les structures élémentaires de la parenté. Paris: Presses Universitaires de France, 1949

LEVI-STRAUSS, Claude. Race et Histoire. Paris: Unesco, 1952.

LINDFORS, Bernth (Ed.). Africans on Stage: Studies in Ethnological Show Business. Bloomington: Indiana University Press, 1999.

LINDFORS, Berth. Le docteur Kahn et les Niam-Niams, in BLANCHARD, Pascal et al. Zoos humains et exhibitions coloniales. 150 ans d'inventions de l'Autre. Paris: La Découverte, 2011. p. 169-180.

MACEY, David. Frantz Fanon. Une vie. Paris: La Découverte, 2013.

MANN, Thomas. Die Stellung Freuds in der modernen Geistesgeschichte. Die Psychoanalytische Bewegung, 1, Heft 1, Mai-Juni, Wien, p. 3-32, 1929.

MARCUSE, Herbert. Eros and Civilization: A Philosophical Inquiry into Freud. Boston: 
Beacon Press, 1955.

MATSCHIE, Paul. Neue Affen aus Mittel-Afrika. Sitzungsberichte des Gesellschaft Naturforschender Freunde zu Berlin, 1914. p. 323-342.

MBEMBE, Achille. Critique de la raison nègre. Paris: La Découverte, 2013.

MCCLINTOCK, Anne. Imperial Leather. Race, Gender and Sexuality in the Colonial Contest. New York: Routledge, 1995.

MERLET, Annie. Paul Belloni Du Chaillu ou l'invention d'un destin. In: HOMBERT Jean-Marie et Louis PERROIS (dir.). Cœur d'Afrique, gorilles, cannibales et Pygmées dans le Gabon de Paul Du Chaillu, Paris: CNRS, 16-47. 2007.

MÉTÉNIER, Oscar. Le Gorille. Paris: Victor Havard Editeur, 1891.

MIGUEL, Francisco. "Sexy Nature": a naturalização da (homo)sexualidade em uma exposição museográfica. Anuário Antropológico, v. 3, n. 1, p. 99-123, 2014.

MOUGUIAMA-DAUODA, Patrick. Récit des villageois sur les gorilles. In: HOMBERT Jean-Marie; PERROIS, Louis (Dir.). Cœur d'Afrique, gorilles, cannibales et Pygmées dans le Gabon de Paul Du Chaillu. Paris: CNRS, 83, 2007.

NOUAILLES, Bertrand. Le Monstre, la vie, l'écart. La tératologie d'Étienne et d'Isidore Geoffroy Saint-Hilaire. Paris: Classiques Garnier, 2017.

OISHI, Takanori. Human-Gorilla and Gorilla-Human: Dynamics of Human-animal boundaries and interethnic relationships in the central African rainforest. Revue de Primatologie, n. 5, 2013. Disponível em: https://journals.openedition.org/ primatologie/1881. Acesso em: 20 out. 2020.

OWEN, Robert. On The Gorilla (Troglodytes Gorilla, Sav.) Proc. Zool. Soc., XXVII, p. 1-23, 1859.

PERCHERON, Bénédicte. Devenir monstre: notions et enjeux de la métamorphose pathologique dans les sciences du vivant et la littérature. Laboratoire LISAA. Les métamorphoses, entre fiction et notion. Littérature et sciences (XVIe-XXIe siècles), p. 265-279, 2019.

SAINT-HILAIRE, Isidore G. Sur les rapports naturels du Gorille; remarques faites à la suite de la lecture de M. Duvernoy. Comptes Rendus Hebdomadaires des Séances de l'Académie des Sciences, n. 36, p. 933-936, 1852.

SAVAGE, Thomas S. Communication describing the external character and habits of a new species of Troglodytes (T. gorilla). Boston Journal of Natural History, p. 245$247,1847$.

SAVAGE, Thomas S.; WYMAN, J. Notice of the external characters and habits of Troglodytes gorilla, a new species of orang from the Gaboon River, osteology of the same. Boston Journal of Natural History, v. 5, p. 417-443, 1847.

SCHWARCZ, Lilian Moritz. O espetáculo das raças. Cientistas, instituições e questão racial no Brasil. 1870-1930. São Paulo: Companhia das Letras, 1993.

SPENCER, Herbert. The Study of Sociology. New York: Appleton and Company, 1873.

STOLER, Ann Laura. Making the empire respectable: The politics of race and morality in 20th century colonial cultures. American Ethnologist, n. 16, p. 634-660, 1989.

STOLER, Ann Laura. Race and the Education of Desire: Foucault's History of Sexuality and the Colonial Order of Things. Durham: Duke University, 1995.

STOLER, Ann Laura. Carnal Knowledge and Imperial power: Race and the Intimate in Colonial Rule. Berkeley: University of California Press, 2002. 
Sílvio Marcus de Souza Correa

STRUYS, Jean. Les voyages de Jean Struys en Moscovie, en Tartarie, aux Inde et en d'autres pays étrangers. Amsterdam: Chez la veuve Jacob van Meurs, 1681.

THOMAS, Greg. The Sexual Demon of Colonial Power. Pan-African Embodiment and Erotic Schemes of Empire. Bloomington; Indianapolis: Indiana University Press, 2007.

TORT, Patrick. L'effet Darwin, Sélection naturelle et naissance de la civilisation. Paris: Seuil, 2008.

VIAUX, Roland. Enfants du néant et mangeurs d'âmes. Guerre, culture et société en Iroquoisie ancienne. Montréal: Les éditions Boréal, 2000.

VOGT, Carl. Vorlesungen über den Menschen, seine Stellung in der Schöpfung und in der Geschichte der Erde. Giessen: Ricker, 1863.

WIGGER, Iris. "Black Shame". The campaign against "racial degeneration" and female degradation in interwar Europe. Race \& Class, v. 51, n. 3, p. 33-46, 2010.

YOUNG, Robert. Colonial Desire: Hybridity in Theory, Culture and Race. London: Routledge, 1995. 